\title{
BNREL
}

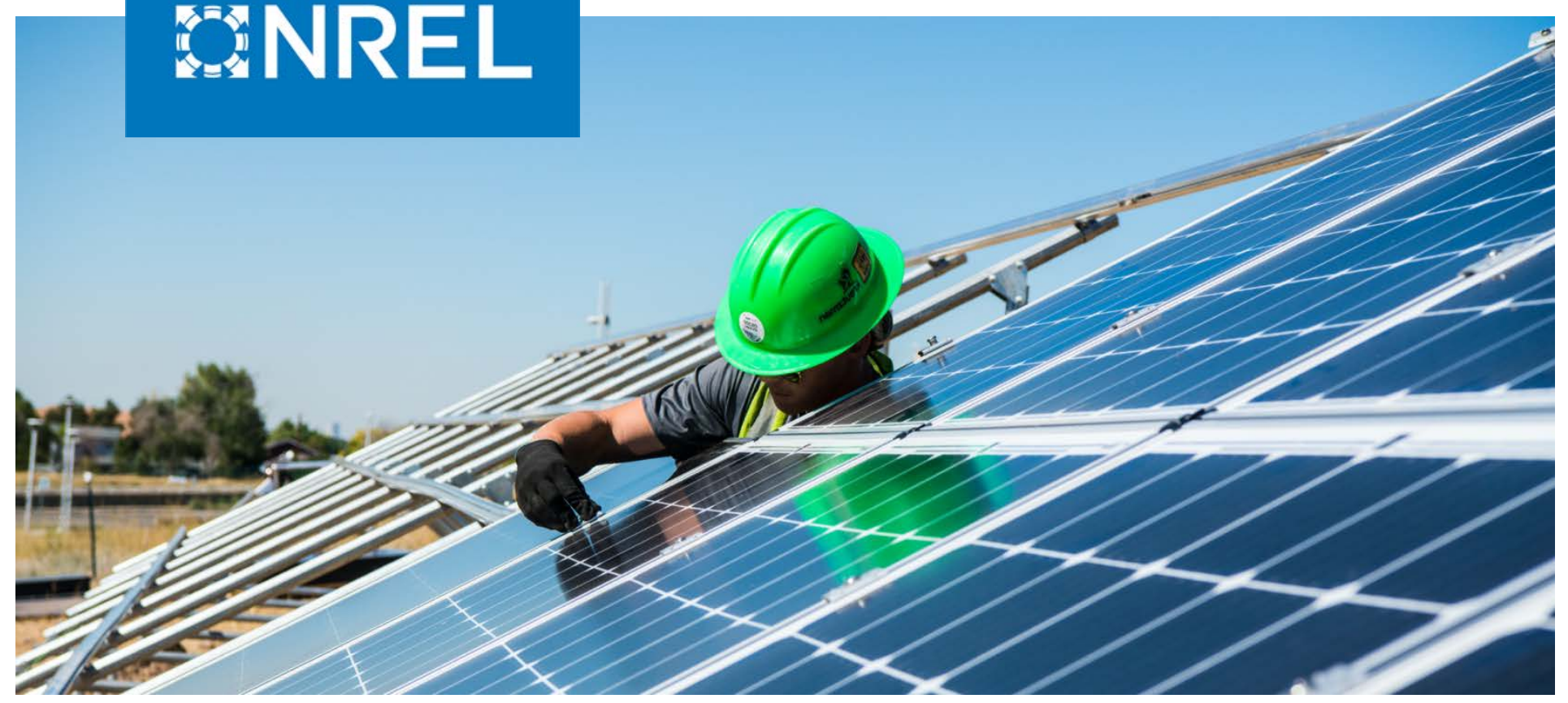

\section{Affordable and Accessible Solar for All: Barriers, Solutions, and On-Site Adoption Potential}

Jenny Heeter, Ashok Sekar, Emily Fekete, Monisha Shah, and Jeffrey J. Cook

National Renewable Energy Laboratory

NREL is a national laboratory of the U.S. Department of Energy Office of Energy Efficiency \& Renewable Energy

Operated by the Alliance for Sustainable Energy, LLC

This report is available at no cost from the National Renewable Energy Laboratory (NREL) at www.nrel.gov/publications.

\section{Technical Report}

NREL/TP-6A20-80532

September 2021 


\section{GNREL}

\section{Affordable and Accessible Solar for All: Barriers, Solutions, and On-Site Adoption Potential}

Jenny Heeter, Ashok Sekar, Emily Fekete, Monisha Shah, and Jeffrey J. Cook

National Renewable Energy Laboratory

\section{Suggested Citation}

Heeter, Jenny, et al. 2021. Affordable and Accessible Solar for All: Barriers, Solutions, and On-Site Adoption Potential. Golden, CO: National Renewable Energy Laboratory. NREL/TP-6A20-80532. https://www.nrel.gov/docs/fy21osti/80532.pdf.

NREL is a national laboratory of the U.S. Department of Energy Office of Energy Efficiency \& Renewable Energy Operated by the Alliance for Sustainable Energy, LLC

This report is available at no cost from the National Renewable Energy Laboratory (NREL) at www.nrel.gov/publications.

Contract No. DE-AC36-08GO28308
Technical Report

NREL/TP-6A20-80532

September 2021

National Renewable Energy Laboratory 15013 Denver West Parkway Golden, CO 80401 303-275-3000 • www.nrel.gov 


\section{NOTICE}

This work was authored by the National Renewable Energy Laboratory, operated by Alliance for Sustainable Energy, LLC, for the U.S. Department of Energy (DOE) under Contract No. DE-AC36-08GO28308. Funding provided by U.S. Department of Energy Office of Energy Efficiency and Renewable Energy Solar Energy Technologies Office. The views expressed herein do not necessarily represent the views of the DOE or the U.S. Government.

This report is available at no cost from the National Renewable Energy Laboratory (NREL) at www.nrel.gov/publications.

U.S. Department of Energy (DOE) reports produced after 1991 and a growing number of pre-1991 documents are available free via www.OSTI.gov.

Cover Photo by Dennis Schroeder: NREL 40820.

NREL prints on paper that contains recycled content. 


\section{The Solar Futures Study and Supporting Reports}

The Solar Futures Study, initiated by the U.S. Department of Energy (DOE) Solar Energy Technologies Office and led by the National Renewable Energy Laboratory (NREL), envisions how, over the next few decades, solar could come to power $40 \%$ or more of U.S. electricity demand, dramatically accelerating the decarbonization of buildings, transportation, and industry.

Through state-of-the-art modeling, the Solar Futures Study is the most comprehensive review to date of the potential role of solar in decarbonizing the U.S. electric grid and broader energy system. However, not all the detailed analysis that informed the Solar Futures Study could be included within its pages. This further analysis is collected in additional National Renewable Energy Laboratory reports, each dedicated to a different technology or socioeconomic concern.

This report, Affordable and Accessible Solar for All: Barriers, Solutions, and On-Site Adoption Potential, focuses on a particular set of economic and social considerations related to the decarbonization of the U.S. energy system.

\section{The Solar Futures Study Reports}

- Solar Futures Study (main report published by DOE)

- Research Priorities for Solar Photovoltaics in a Decarbonized U.S. Grid

- $\quad$ The Role of Concentrating Solar-Thermal Power Technologies in a Decarbonized U.S. Grid

- $\quad$ The Demand-Side Opportunity: The Roles of Distributed Solar and Building Energy Systems in a Decarbonized Grid

- Maximizing Solar and Transportation Synergies

- The Potential for Electrons to Molecules Using Solar Energy

- Affordable and Accessible Solar for All: Barriers, Solutions, and On-Site Adoption Potential

- Forthcoming Environment and Circular Economy Report

You can learn more about the project and reports on the NREL website at https://www.nrel.gov/analysis/solar-futures.html. 


\section{List of Acronyms and Abbreviations}

AMI

ATB

BAU

GW

LMI

Msqft

$\mathrm{MW}_{\mathrm{AC}}$

NREL

PV

REPLICA

SREC

W area median income

Annual Technology Baseline

business as usual

gigawatts

low- and moderate-income

million square feet

megawatts-alternating current

National Renewable Energy Laboratory

photovoltaics

Rooftop Energy Potential of Low Income Communities in America

Solar Renewable Energy Certificates

watt 


\section{Table of Contents}

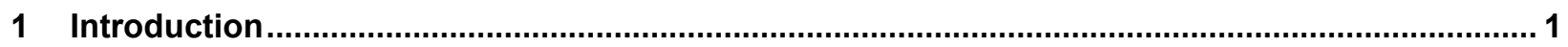

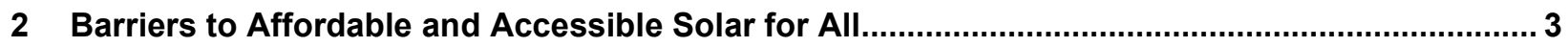

3 Modeling Low- and Moderate-Income On-Site Solar Adoption ................................................ 10

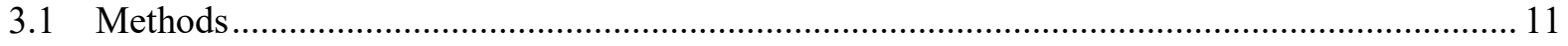

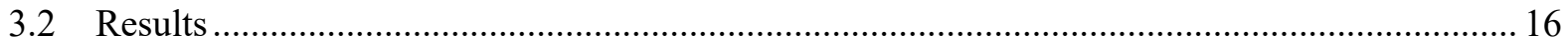

4 Transforming Low- and Moderate-Income Solar Adoption? ...................................................... 24

4.1 Pathways to Expanding LMI Solar Adoption ............................................................. 24

4.1.1 Finance and Funding .............................................................................. 25

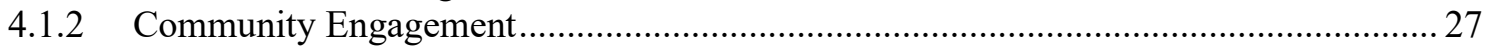

4.1.3 Site Suitability ......................................................................................... 28

4.1.4 Other Policy and Regulation Solutions ........................................................... 29

4.1.5 Resilience and Recovery ............................................................................ 30

4.1.6 Emerging Structures ............................................................................... 30

4.2 Challenges to LMI Solar Adoption .................................................................... 30

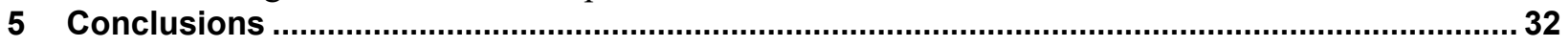

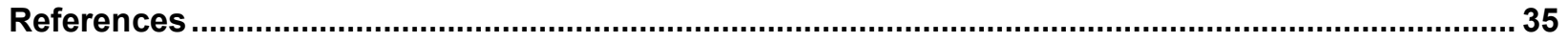




\section{List of Figures}

Figure 1. Modeled rooftop solar area by building tenure and occupant income (inputs) ........................ 13

Figure 2. PV price scenarios in the Solar Futures Study ................................................................... 15

Figure 3. Adoption of solar in owner-occupied buildings, PV price, and incentive impacts.................... 17

Figure 4. Impact of lower PV prices and the split incentive scenarios on solar adoption by renters.......... 19

Figure 5. Impact of policy incentives and split incentives on solar adoption by renters ......................... 20

Figure 6. Range of average first-year gross bill savings for each market segment, between 2020 and 2050,

all scenarios (ATB Moderate Prices and Partially Addressed split incentives) .................... 21

Figure 7. Percentage change in average LMI household energy burden when installing PV (2050) ........ 22

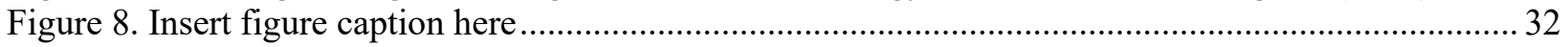

\section{List of Tables}

Table 1. Summary of Barriers to Low-Income Solar Adoption.............................................................5

Table 2. Deployment of Midsized ( 10-MW) Urban Distributed Ground-Mounted PV Systems in the

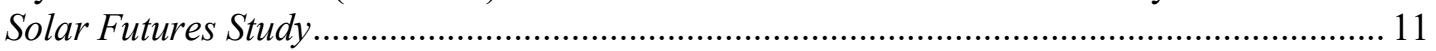

Table 3. Building and Energy Characteristics by Household Type .................................................... 12

Table 4. Discount Rate Assumptions by Income Bracket and Tenure..................................................... 14

Table 5. Cumulative Results of the Incentives Scenarios on Low- and Moderate-Income Households between 2020 and 2050 (Partially Addressed split incentive, ATB Moderate Price)............ 23

Table 6. Short- and Long-Term Solutions to LMI Solar Adoption Barriers. 


\section{Introduction}

As the main scenarios in the Solar Futures Study (DOE 2021) demonstrate, in 2035, the reference case and two alternate scenarios (Grid Decarbonization and High Electrification) show similar electricity system costs. ${ }^{1}$ This is a result of these scenarios including technology advancements that continue to bring down the cost of renewable energy. By 2050, however, the Grid Decarbonization and High Electrification cases have higher average systems cost of electricity; notably, technology advancements also help lower costs for these scenarios. These findings suggest that (1) technology advancements play a key role in keeping costs low for all customers, which is particularly important for low-income electricity consumers and (2) in cases where electricity system costs increase, helping low-income consumers lower their bills via customer solar options or other methods (e.g., efficiency and rate design) is increasingly important. $^{2}$

Solar energy technologies can be used as part of a suite of tools to reduce the energy burden of low-income customers, but to date, low-income customers have not adopted solar at the same rate as other income groups. Low-income customers are particularly exposed to the impacts of changing electricity bills, as they pay a higher percentage of their income in utility bills, which results in a disproportionally higher energy burden. The median energy burden for low-income households is $8.1 \%$, which is more than three times that of non-low-income households at $2.3 \%$ (Drehobl, Ross, and Ayala 2020).

Low- and moderate-income (LMI) households, which include multifamily and renter-occupied buildings, represent $43 \%$ of all U.S. households (Sigrin and Mooney 2018). ${ }^{3}$ However, as of 2018, LMI households comprise 15\% of solar adopters (Barbose et al. 2020). This lack of penetration does not coincide with a lack of potential or disinterest in solar technologies. When multifamily homes and renter-occupied buildings are included, LMI households make up 42\% of residential rooftop potential (Sigrin and Mooney 2018). LMI-owned single-family homes are a key part of the market to consider, as $55.2 \%$ of LMI households own their homes. LMI-owned single-family homes alone make up $31 \%$ of estimated rooftop solar photovoltaic (PV) capacity for all single-family homes (Sigrin and Mooney 2018). And Wolske (2020) found that lowincome and high-income solar adopters are interested in solar for the same reasons: addressing energy issues, savings on bills, and the overall value of solar as a renewable energy.

Granting that the degree of disparity varies significantly by region, findings from recent studies focused on specific areas support these trends (Barbose et al. 2020). Chicago, Illinois; Riverside, California; San Bernardino, California, and Washington, D.C., all exhibit higher rooftop PV penetration located in higher-income census tracts. For Washington, D.C., and Chicago, Reames (2020) found that although the highest solar potential was in LMI census tracts, this did not translate to higher solar adoption. Lukanov and Krieger (2019) analyzed solar adoption rates in

\footnotetext{
${ }^{1}$ ReEDS examines average system cost of electricity - not the electricity prices that consumers pay on their bill. Our simplifying assumption is that if average system costs of electricity increase, those increases would be passed on to electricity consumers.

${ }^{2}$ Under a High Electrification scenario, low-income customers will need protection from being left paying the costs of remaining natural gas facilities.

${ }^{3}$ LMI is defined as households earning $80 \%$ or less of the area median income.
} 
disadvantaged communities and found that census tracts in the top 5\% of the CalEnviroScreen database (i.e., the most disadvantaged communities) have adoption rates 8.2 times lower than those in the bottom $5 \%$ of the CalEnviroScreen (i.e., the least disadvantaged communities). ${ }^{4}$ On a broader scale, a study encompassing California, New York, New Jersey, and Massachusetts, found that households earning $\$ 45,000$ or less annually represented $25 \%$ of the total population in those states but only 13\% of PV installations (Kann and Toth 2017).

Income is not the only variable that impacts solar adoption; levels of rooftop PV penetration also differ by race. Currently, Black and Hispanic households are more likely to experience energy insecurity and utility disconnection (Memmott et al. 2021). Additional data show that rooftop PV adoption rates are significantly lower in Black- and Hispanic-majority census tracts, even when accounting for racial and ethnic differences in household income and home ownership (Sunter, Castellanos, and Kammen 2019). When comparing households with the same median household income, Sunter, Castellanos, and Kammen (2019) found Hispanic-majority census tracts had installed 30\% less rooftop PV than no-majority census tracts; similarly, Black-majority census tracts had installed $69 \%$ less. $^{5}$ This is a stark difference from white-majority census tracts, which had installed 37\% more than no-majority tracts. When controlling for home ownership rates, Sunter, Castellanos, and Kammen (2019) found comparable results: Black-majority census tracts had installed 61\% less rooftop PV than no-majority tracks, and Hispanic-majority tracts had installed $45 \%$ less, while white-majority census tracts had installed $37 \%$ more; this report focuses on income as an indicator of unequal access to solar, partially as a result of data needs related to other demographic indicators.

Community solar and solar on multifamily buildings can also provide solar access pathways to LMI households and households of color. Community solar has become an attractive option for those for whom rooftop PV is not an option, and policies in some states have made it more accessible to LMI customers in recent years. However, as of 2018, less than half of community solar projects in the United States included low-income households, and only 5\% of projects included low-income households as a "sizeable share," which was defined as more than 10\% of subscribers (Gallucci 2019).

We begin this Solar Future Studies report with a review of the market and regulatory barriers to low-income solar access and affordability, and we summarize current solutions to those challenges (Section 2). In Section 3, we model future low-income on-site solar adoption, using the National Renewable Energy Laboratory's (NREL's) dGen model. We expand existing dGen capabilities by creating new agent types by income class, building type (single-family and multifamily), and tenure (renter and owner). We model future scenarios assuming no changes in the current LMI solar policy and program environment, and we add two incentives to lowincome households for adopting solar: a $\$ 3,000$ incentive and a full incentive (i.e., the full cost of a PV system). While we model a financial incentive, this dollar reduction in cost could also come from other efforts, for example, reductions in solar soft costs. In Section 4, we discuss more

\footnotetext{
${ }^{4}$ CalEnviroScreen is a database and geospatial mapping tool that integrates environmental burden and socioeconomic data at the census tract level in California (Rodriquez and Zeise 2017). Disadvantaged communities are defined as the census tracts that score in the top 25\% statewide according to the CalEnviroScreen 3.0 metric; these are the $25 \%$ of California communities that suffer the most from a combination of socioeconomic, health and environmental burdens.

5 "No majority" tracts are those where no single racial or ethnic group comprises more than $50 \%$ of the population.
} 
transformational changes - both positive and negative - that can work either jointly with or separately from the modeled added incentives to influence low-income solar adoption.

\section{Barriers to Affordable and Accessible Solar for All}

Numerous barriers keep low- and moderate-income individuals from being able to access solar for their homes (Table 1); we categorize these barriers as finance and funding barriers, community engagement barriers, site suitability barriers, policy and regulatory barriers, and resilience and recovery barriers.

LMI communities have less disposable income, which means high upfront costs rooftop solar can be a substantial barrier. Even when upfront costs are reduced, they do not always provide an equitable benefit to low-income households. Third-party ownership (TPO) models and community solar may provide low-income households with a smaller financial benefit than highincome households, as LMI customers tend to consume less electricity to begin with, thus seeing smaller reductions in their bills from transitioning to a cheaper solar option. ${ }^{6}$ In addition, some market tools traditionally used in conjunction with renewable energy can disproportionally affect low-income households with added financial burdens. For example, some utilities increase their fixed costs to all customers, which can increase low-income customers' energy burden even more (O’Connor 2018).

Although several solar incentives and financing mechanisms are in place to reduce the expenses associated with installing solar, some are still not as accessible to LMI customers. These individuals often have low credit scores, which excludes them from typical financing mechanisms such as loans or power purchase agreements that have minimum requirements (Cook and Bird 2018). To date, residential solar adoption has occurred primarily in households with high incomes and high credit scores, as almost $90 \%$ of solar adopters have been reported to have prime credit scores (680-740) or super-prime credit scores (>740) (Barbose et al. 2020). Nearly $30 \%$ of low-income consumers are credit invisible, and another $15 \%$ have unscored records; these are significantly higher percentages than those found in high income neighborhoods (Brevoort, Grimm, and Kambara 2015). Insufficient tax burdens and timing issues can also exclude them from tax credit incentives like the federal investment tax credit for solar. Borenstein and David (2016) found that households with annual income of $\$ 75,000$ or more received $62 \%$ of the residential energy tax credits. Nonprofit organizations and tribes, which are ineligible for tax incentives, cannot apply the investment tax credit to serve LMI communities without partnering with private entities. Nor, for similar reasons, can LMI households, nonprofits, and tribes take advantage of some additional local and state income or property tax incentives.

Because low-income communities have historically not been targeted for solar investment, they can be generally unfamiliar with solar products. ${ }^{7}$ Also, because these communities have been

\footnotetext{
${ }^{6}$ The U.S. Energy Information Administration's Residential Energy Consumption Survey indicates energy consumption increases correlate with increased annual household income (EIA 2018).

${ }^{7}$ Peer effects can play a role in solar adoption, though it has been found that there are not significant differences in these drivers between income groups. Low-income and high-income solar adopters are alike in terms of the key determinants of solar adoption, including the sense of personal obligation to address energy issues, savings on energy bills, and desire to demonstrate the value of solar as a renewable energy (Wolske 2020).
} 
targeted for scams and exploitation, they can be distrustful of promises of energy savings, making consumer protection measures even more important. Language barriers and lack of internet access can compound the issue by increasing the lack of access to information; more than 25 million Americans have a first language other than English, and lack of accessibility for limited English-proficient communities has also been linked as an impediment to environmental participation and decision making (Teron and Ekoh 2018). About 44\% of households with incomes below $\$ 30,000$ a year do not have access to home broadband services (Perrin 2018). And in some cases, lack of internet access has been found to negatively associate with rooftop solar penetration (Reames 2020). The increased expenses and more deliberate trust-building efforts required for LMI customer acquisition can discourage general market interest in these communities.

Those who own single-family homes often face housing-related barriers to adopting rooftop PV, such as rooftop suitability and faulty or dated electrical wiring. Roofs best suited for solar have strong infrastructure, have no leaks, and must not require any significant maintenance at the time of installation. Low-income families are more likely to live in older homes than high income families and therefore are more likely to need the costly upgrades to their homes to host on-site solar arrays (Fernald 2013). In addition, older homes often host asbestos, lead, and mold, which can make home repairs more complicated and can result in added costs to the owner (Snell et al. 2000). This disparity stems from a history of suburbanization, redlining, and discriminatory housing policies that have resulted in people of color and LMI families being more likely to live in older homes that need costly repairs and upgrades (Holtje 2020).

Renting can present its own significant barriers to accessing solar. As of 2020, low-income households accounted for 38\% of the rental market (Joint Center for Housing Studies 2020). Renters currently subject to utility allowance rules set by the U.S. Department of Housing and Urban Development, which provide flat rent and electric bills, cannot reduce their bills any further with solar. ${ }^{8}$ Additionally, Black and Hispanic households are more likely to rent, as 58\% of Black households and 54\% of Hispanic households rent their homes (Sunter, Castellanos, and Kammen 2019). Renter barriers to solar include ineligibility for specific tax credits. For example, renters are not eligible for the Residential Energy Efficient Property Credit, a tax credit that can be applied for renewable energy installation. This is significant, as the credit totaled $\$ 3.5$ billion in tax expenditures between 2005 and 2012, with 54\% going to solar panels at an average above $\$ 5,000$ per household (Borenstein and Davis 2016). Additionally, renters are not eligible for the federal investment tax credit, though in some circumstances a property owner can claim the credit under Section 48 , which provides a credit to commercial property owners. ${ }^{9}$

Additional barriers include split incentives and challenges associated with tenants lacking the authority or bill crediting mechanism to take advantage of on-site solar. For example, some renters pay their own utility bills, and some share a meter, splitting their electric payments with other tenants of the building. Additionally, more than $25 \%$ of renters have utilities included in their cost of rent, which allows them less control and flexibility over their power source

\footnotetext{
${ }^{8}$ California's Solar on Multifamily Affordable Housing program was granted an exception. Some groups have called for that exception to be extended nationally (see for example, Kienbaum and Ferrell 2021).

${ }^{9}$ Homeowner's Guide to the Federal Tax Credit for Solar Photovoltaics," U.S. Department of Energy Office of Energy Efficiency and Renewable Energy, https://www.energy.gov/eere/solar/homeowners-guide-federal-tax-creditsolar-photovoltaics.
} 
(Levinson and Niemann 2004). When a tenant does not have direct autonomy over their utility bill, they must seek approval from the property owner or other tenants who would need to approve the decision to invest in solar.

Both renters and unit owners residing in multifamily affordable housing face additional barriers to those faced by renters of single-family homes. They must also seek the approval of the property owner to invest in solar but might not fully reap the benefits. A property owner may also choose to invest in rooftop PV to reduce their own utility bills for master-metered properties or common areas, resulting in distributed benefits which may not reach the residents of the building. Policies for housing assistance for residents and for operational assistance for owners can acquiring and benefiting from solar on multifamily affordable housing procedurally complex and challenging. The U.S. Department of Housing and Urban Development created its Renew300 initiative to (1) help federally assisted housing properties manage utility costs through the installation of onsite or community-based renewable energy and (2) provide technical assistance to affordable housing providers, which can aid them navigate solar-related incentives and polices.

Low-income households face many of the same barriers to offsite community solar as are faced with traditional rooftop solar, including financing, education, and outreach. In addition, a lack of enabling policies keeps community solar from flourishing in some states, removing it as an option for interested households. In states where community solar is enabled, no low-income specific component might be available to those interested in subscribing. Consumer protection measures such as the ability to cancel or transfer subscriptions without penalty are also important for members of LMI households, who may relocate more often and who are particularly burdened by increased costs in any given month.

For both rooftop and community solar, widely varying policy frameworks among states, localities, and utilities can pose their own barriers. Solar incentives and policies can be piecemeal and not well integrated with other programs and incentives, leading to confusion and inefficiency. Low-income solar programs can also suffer from failure to ensure long-term funding and continuity. High "soft costs," such as costs related to permitting and interconnection delays, also can especially burden LMI households.

Table 1. Summary of Barriers to Low-Income Solar Adoption

\begin{tabular}{|l|l|}
\hline $\begin{array}{l}\text { Barriers to Low- } \\
\text { Income Solar Adoption }\end{array}$ & Details \\
\hline $\begin{array}{l}\text { Finance and funding } \\
\text { barriers }\end{array}$ & $\begin{array}{l}\text { Inability to afford an upfront solar payment } \\
\text { Difficulty accessing low-cost financing options for solar/low or no } \\
\text { credit score } \\
\text { Limited LMI specific incentives, credits, or financing mechanisms to bring } \\
\text { down the cost of solar and enable bill savings from day one } \\
\text { LMI incentives that may exclude community-based organizations, tribal } \\
\text { entities, and others } \\
\text { Varying utility bill payment structures, resulting in lack of bill autonomy } \\
\text { for renters } \\
\text { Lack of financial motivation for property owners to reduce tenant } \\
\text { electricity bills }\end{array}$ \\
\hline
\end{tabular}




\begin{tabular}{|c|c|}
\hline \multirow[t]{3}{*}{$\begin{array}{l}\text { Barriers to Low- } \\
\text { Income Solar Adoption }\end{array}$} & Details \\
\hline & $\begin{array}{l}\text { Inability or unwillingness of property owners to pass on savings from solar } \\
\text { to tenants in master metered buildings }\end{array}$ \\
\hline & $\begin{array}{l}\text { LMI households without tax appetite to benefit directly from the federal } \\
\text { investment tax credit }\end{array}$ \\
\hline \multirow[t]{5}{*}{$\begin{array}{l}\text { Community engagement } \\
\text { barriers }\end{array}$} & $\begin{array}{l}\text { Lack of information on solar in LMI communities because of market } \\
\text { disinterest, lack of outreach and technical assistance to LMI community } \\
\text { organizations, language barriers, failure of solar representatives to engage, } \\
\text { or other causes }\end{array}$ \\
\hline & $\begin{array}{l}\text { Lower solar adoption rates that are due to peer effects (Seeing neighbors } \\
\text { adopt solar leads to increased solar adoption.) }\end{array}$ \\
\hline & $\begin{array}{l}\text { Low level of trust for solar technologies and developers, paired with } \\
\text { contracts and bill crediting schemes that can be time-consuming to } \\
\text { understand }\end{array}$ \\
\hline & $\begin{array}{l}\text { Trusted organizations lacking the capacity to include solar in the } \\
\text { information and services they offer to LMI communities }\end{array}$ \\
\hline & $\begin{array}{l}\text { Limited capacity to participate in utility and regulatory processes because of } \\
\text { their highly technical, expensive, and difficult-to-navigate proceedings, } \\
\text { resulting in programs that reflect lack of community input and are not well } \\
\text { designed to meet LMI household needs }\end{array}$ \\
\hline \multirow[t]{3}{*}{ Site suitability barriers } & $\begin{array}{l}\text { Higher proportions of old roofs and roofs in need of repair or replacement } \\
\text { before solar can be installed }\end{array}$ \\
\hline & $\begin{array}{l}\text { Increased needs for home improvement measures before solar can be } \\
\text { installed (e.g., updating of electrical wiring or service panels) }\end{array}$ \\
\hline & $\begin{array}{l}\text { Lack of decision making authority for making solar investments in cases } \\
\text { where LMI individuals reside in rental homes, apartments, condos, or } \\
\text { multifamily affordable housing units }\end{array}$ \\
\hline \multirow[t]{5}{*}{$\begin{array}{l}\text { Policy and regulatory } \\
\text { barriers }\end{array}$} & $\begin{array}{l}\text { Absence of enabling legislation for community solar in some states } \\
\text { Absence of adequate consumer protections in place for low-income } \\
\text { customers }\end{array}$ \\
\hline & $\begin{array}{l}\text { Solar incentives and policies that can be piecemeal, inconsistent over time, } \\
\text { and not well integrated with other programs and incentives, such as energy } \\
\text { assistance, home and vehicle electrification efforts, and disaster planning } \\
\text { and mitigation }\end{array}$ \\
\hline & $\begin{array}{l}\text { "Soft costs" such as permitting and interconnection delays, especially for } \\
\text { LMI households }\end{array}$ \\
\hline & $\begin{array}{l}\text { Some energy policies that might result in adverse effects for LMI } \\
\text { households, including nonadopters }\end{array}$ \\
\hline & $\begin{array}{l}\text { Energy programs for LMI households that are sometimes siloed in separate } \\
\text { agencies, resulting in inefficiencies and lack of holistic energy offerings that } \\
\text { would include solar and other solutions as part of a package }\end{array}$ \\
\hline \multirow[t]{2}{*}{$\begin{array}{l}\text { Resilience and recovery } \\
\text { barriers }\end{array}$} & $\begin{array}{l}\text { LMI households face more adverse effects of natural disaster and } \\
\text { economic hardship }\end{array}$ \\
\hline & $\begin{array}{l}\text { Inability of LMI households to take advantage of disaster recovery funds at } \\
\text { the same rate as higher-income households }\end{array}$ \\
\hline
\end{tabular}




\section{Existing Solutions to Address LMI Solar Barriers}

Even with considerable barriers, solar adoption has been gradually migrating toward lower income ranges over time (Barbose et al. 2020). In this section, we discuss existing and emerging solutions to address LMI solar barriers. ${ }^{10}$

The shift toward increasing income diversity in on-site solar adoption reflects the expanding U.S. solar market, as well as expansion of alternatives to rooftop PV, policy changes, and financing mechanisms. Third-party ownership, for example, has become a prominently adopted financing solution for LMI customers to access solar. Under third-party ownership, a developer owns, operates, and maintains the PV system, resulting in up-front costs to the customer that are lower than the costs of purchasing a PV system themselves. Among LMI solar adopters in 2016, $57 \%$ opted for a third-party ownership structure and $48 \%$ of non-LMI adopters went this route (Barbose et al. 2018).

For LMI customers applying for solar incentives and financing options, having a low credit score can be their core barrier to entry. Alternatives to FICO credit scores have been designed to both be more inclusive of LMI customers and reduce the risk of delinquency. EnergyScore, a customer risk indicator designed by researchers at Stanford, the Massachusetts Institute of Technology, and Solstice, can predict the delinquency of customers under credit scores ranging from 650 to 730 . EnergyScore is more inclusive of LMI customers than FICO and has expanded access to households earning $80 \%$ or less of the sample median income of $\$ 50,000$ (Solstice 2018).

A loan loss reserve, such as the Mass Solar Loan Program, is another option to allow those with low credit scores access to solar financing. The loan loss reserve is a fixed renewable account that acts as a form of insurance to lenders by containing public funds held in reserve to cover potential losses that loan providers may incur if a customer defaults on a loan. For loans without a loss reserve, underwriting criteria can be adapted to be more inclusive of LMI customers. Expanding thresholds of traditional metrics, employing alternative metrics such as past utility bill repayment or EnergyScore, or a hybrid approach of the two can expand access to customers with lower credit scores.

Other financing options have been used to expand solar access to low-income communities, such as on-bill financing and direct incentives. On-bill financing, a practice not dependent on credit scores, is used to recover funds directly through a customer's electric utility bill. Reducing the number of bills received and having the utility bill savings from solar offsetting loan payments in one place make the financing easier to understand. Some cities and states such as Washington D.C. offer incentive programs to cover the cost of these systems directly. D.C.'s Solar for All Program provides incentives for community solar systems that can benefit multifamily residential homes regardless of home ownership or renter status, as well as no-cost rooftop solar installations to both renters and homeowners who are income qualified. Illinois' Solar for All program similarly offers incentives for low-income single-family residences, and it recently saw installed the first of these single-family systems to benefit five families living on Chicago's South Side. These incentive programs are key to increasing solar deployment to LMI

\footnotetext{
${ }^{10}$ In Section 4, we discuss solutions for the 2035 and 2050 time-frames.
} 
households, as incentives targeted toward LMI households are a key driver of more equitable PV adoption (O’Shaughnessy et al. 2021).

Weatherization and energy efficiency funds are also being used to help deploy rooftop solar installations to low-income communities in at least two states. Colorado was the first state integrate PV into its weatherization assistance program, using funds from the U.S. Department of Energy's Weatherization Assistance Program and the U.S. Department of Health and Human Services' Low Income Home Energy Assistance Program. By applying these funds, the Colorado Energy Office has been able to deploy rooftop solar to customers spending more than $4 \%$ of household income on energy costs (Cook and Shah 2018). California's Low-Income Weatherization Program has also prioritized solar PV in its weatherization goals, and it has seen more than 2,900 no-cost solar PV systems installed as of March 2018 (California Department of Community Services and Development 2018).

Community solar is prominent alternative to rooftop PV for low-income customers is. It is attractive to those who face barriers to entry for traditional rooftop PV because community solar does not require rooftop installation, and it is accessible to renters as well as those with insufficient roof conditions to support a rooftop PV system. Increasingly, in the major community solar markets, subscribers are not paying upfront costs for their subscriptions and are saving $5 \%-15 \%$ on their electricity bills. As of 2020 , more than $1,184 \mathrm{MW}_{\mathrm{AC}}$ of community solar has been deployed; and more states have been incentivizing low-income inclusion in community solar programs, making it more accessible than in previous years (Heeter, O'Shaughnessy, and Chan 2020). States are doing this via a mix of LMI community solar mandates, incentives for LMI participation, and grant funding. The Colorado Energy Office, for example, launched its low-income community solar demonstration project in 2015 to help reduce customers' energy burdens. A total of \$1.2 million was granted to support co-op and municipal community solar projects, resulting in eight implemented projects totaling over $1.5 \mathrm{MW}$ of capacity of capacity and serving more than 380 low-income customers. And the project has since grown, adding funding for $20 \mathrm{MW}$ of $100 \%$ low-income community solar projects in investorowned utility territories (Heeter et al. 2018). Fifteen states and Washington, D.C., have added provisions to prioritize and encourage the inclusion of LMI subscribers in community solar. In 2021, the State of New Mexico passed legislation requiring a community solar program and included a 30\% carve-out for LMI customers. States like Maryland, Connecticut, and Colorado also use a portfolio-based approach to LMI community solar, requiring a specific carve-out of the generation produced to be subscribed by LMI customers. Other states have adopted incentive and grant programs to encourage LMI participation in community solar.

Low-income families living in multifamily affordable housing have gained access to solar through less traditional channels. California and Washington, D.C., have active multifamily affordable housing solar programs, and Massachusetts has introduced incentives specific to multifamily solar adoption. In the District's initial round of projects under its Solar for All program, the Department of Energy and Environment designated \$8 million to install 4-8 MW of new solar capacity on multifamily homes, as well as commercial buildings and nonresidential surface spaces (GRID Alternatives and Vote Solar 2018). The Solar Massachusetts Renewable Target Program awards a higher price for solar renewable energy credits generated by projects that are considered low-income community-shared solar or that serve low-income property such 
as affordable housing, as did its predecessor the Solar Renewable Energy Certificates-II (SRECII) program.

To bring solar to multifamily affordable housing units in California, the Solar on Multifamily Affordable Housing program was introduced in June 2019. This new program marked a transition away from the previous program, the Multifamily Affordable Solar Housing Program. The new incentive program uses cap-and-trade funding streams directed from the electric investor-owned utility's "greenhouse gas auction proceeds." This funding source allows $\$ 100$ million to be directed toward subsidized solar energy systems on multifamily affordable housing each year, substantially increasing the funding granted through the program. The program focuses on bringing solar to the State's most disadvantaged communities, identified through CalEnviroScreen.

In some utility service territories, utility-supplied PV can also be an option for LMI customers. In 2018, the utility-scale sector, which includes projects larger than $5 \mathrm{MW}_{\mathrm{AC}}$, accounted for approximately $60 \%$ of all new solar capacity (Bolinger, Seel, and Robson 2020); though these projects do not typically result in significant bill reduction for low-income customers, structures are emerging to do so. For example, the Imperial Irrigation District in California launched a program in late 2019 to supply $30 \mathrm{MW}$ of solar to its more than 12,000 low-income customers. The solar program provides up to $5 \%$ savings on each customer's monthly electric bill, which is in addition to the already offered $20 \%$ discount to income qualifying customers (Imperial Irrigation District 2019). 


\section{Modeling Low- and Moderate-Income On-Site Solar Adoption}

To understand the potential for low- and moderate-income (LMI) solar adoption, assuming barriers identified in Section 2 are partially or fully mitigated, we build on NREL's existing dGen model, which has traditionally focused on single-family owner-occupied household adoption of solar systems, to include the adoption of solar in multifamily buildings and with renter-occupied buildings. We also expand dGen to consider the financial barriers, suitable roof space, and energy consumption of three income groups and the impact of different solar prices and incentives on adoption by LMI households. Lastly, we consider the impact of these adoption decisions on utility bill savings and the potential to have a lasting impact on energy burden for LMI households.

We focus on on-site rooftop PV access, though ground-mounted community solar and lower cost utility-scale solar can also provide benefits to low-income households. Lower-cost utility-scale solar is explored in DOE (2021) and could result in lower retail utility rates which could have a meaningful impact on energy burden. Community solar is also another very relevant option for low-income households to gain access to solar, especially for those homeowners with a roof which is unsuitable for solar or renters.

We include new capabilities to explore the adoption of solar multifamily buildings; these solar projects could be implemented as community solar, shared solar, or behind-the-meter solar. We do not model traditional community solar projects, which are typically ground-mounted and not connected to building load.

Different types of benefits may be associated with different scales of solar (e.g., single-family rooftop solar versus ground-mounted community solar versus utility-scale solar). Those benefits could include:

- Direct or indirect electricity bill reduction

- Economic benefits to the participant and community, in particular, depending on the size and location of the installed PV system

- Noneconomic benefits (e.g., community ownership)

- Social welfare benefits.

This analysis focuses on modeling customer adoption of rooftop solar options for single-family homes and multifamily buildings; we do not model adoption of ground-mounted solar arrays that could provide solar access to LMI consumers via community solar or other pathways. For example, the mid-sized, ground-mounted solar capacity installed in the Solar Futures Study scenarios could be used for community solar, though those projects are larger in size than the average community solar project to date ( $<2 \mathrm{MW})$. In the Solar Futures Study scenarios, 37-96 GW urban-sited, ground-mounted midsized systems ( $10 \mathrm{MW})$ are installed through 2050 (Table 2). 
Table 2. Deployment of Midsized ( 10-MW) Urban Distributed Ground-Mounted PV Systems in DOE (2021)

\begin{tabular}{|l|l|l|}
\hline Scenario & $\mathbf{2 0 3 5 / 3 6}$ & $\mathbf{2 0 5 0}$ \\
\hline Reference & $23.7 \mathrm{GW}$ & $37.3 \mathrm{GW}$ \\
\hline Grid Decarbonization $^{\mathrm{a}}$ & $40.9 \mathrm{GW}$ & $57.7 \mathrm{GW}$ \\
\hline High Electrification $^{\mathrm{a}}$ & $53.7 \mathrm{GW}$ & $95.6 \mathrm{GW}$ \\
\hline
\end{tabular}

a The Reference scenario uses the NREL Annual Technology Baseline (ATB) moderate cost projection, and the Grid Decarbonization and High Electrification scenarios use the ATB advanced utility solar cost projections. Other assumptions regarding these scenarios can be found in DOE (2021).

Another consideration in this analysis is that marginalized or underserved communities can be defined by several characteristics (e.g., disproportionate environmental impacts, communities of color, access to affordable housing, and employment) and in this analysis, we focus primarily on income as an indicator of unequal access to solar. We build on existing work funded through the U.S. Department of Energy's Solar Energy Technologies Office, including the Rooftop Energy Potential of Low Income Communities in America (REPLICA) data set, which provides solar technical potential data for each census tract, by income, building type, and tenure.

\subsection{Methods}

To date, NREL has used the dGen model to forecast solar adoption by single-family owneroccupied households. Because many low-income households reside in multifamily, and renteroccupied buildings, we developed - for the Solar Futures Study — new capabilities in dGen to forecast the adoption of solar by low-and moderate-income households that reside in both multifamily or renter-occupied dwellings. ${ }^{11}$ With the expanded representation of LMI households in DGen, we determined the influence of incentives, solar prices, and other decision parameters (e.g., discount rate) on LMI adoption of distributed solar.

The first step in expanding representation of LMI solar adoption in dGen was to develop agent profiles of LMI, multifamily, and renter-occupied households. Next, we modeled agent decisions using the Bass diffusion model (Bass 1969). Because each household type has different financial outlook, consumer decision of each household type was modeled by changing the respective inputs to the Bass model. In this section, we describe the agent profile development process and consumer decision making.

\footnotetext{
${ }^{11}$ We rely on the assumptions used in the main scenario modeling for dGen, including the net metering provisions. We assume net metering (NEM) policies are phased out based on the end dates specified by utilities that currently offer it, and we assume the utility moves to net billing after the end date. Typical NEM policy phaseout is in 2030. For any utility that has NEM but no prescribed closing date, dGen evaluates those consumers based on the state in which they reside. Depending on the state's historical policies and favorability toward solar, a threshold value is developed in the form of percentage of maximum cumulative capacity NEM is valid. Once a state's cumulative capacity reaches the threshold, NEM expires for that state and switches to net billing. NEM phase-out year in this case depends on the rate of adoption. In some states (e.g., South Dakota), there are no net metering policies; in those cases, no net billing or net metering is assumed.
} 
To develop the new agent profiles, we used the REPLICA data set (Mooney et al. 2018). It provides estimates of rooftop solar technical potential by tract, categorized by:

- Income: very low (0\%-30\% area median income [AMI]), low (30\%-0\% AMI), moderate (50\%-80\% AMI), medium (80\%-120\% AMI), and high ( $>120 \%$ AMI)

- Household type: single-family and multifamily

- Tenure: owner/renter-occupied.

For the purpose of this report, we aggregate income into low, moderate, and high categories as shown in Table 3 and Figure 1.

Table 3. Building and Energy Characteristics by Household Type

\begin{tabular}{|c|c|c|c|c|c|}
\hline Income & $\begin{array}{l}\text { Building } \\
\text { Type }\end{array}$ & Tenure & $\begin{array}{l}\text { Number of } \\
\text { buildings } \\
\text { (millions) }\end{array}$ & $\begin{array}{l}\text { Suitable } \\
\text { roof area } \\
\left(\text { million } \mathrm{ft}^{2}\right)\end{array}$ & $\begin{array}{l}\text { Average Annual } \\
\text { Energy Consumption } \\
\text { per Building (kWh) }\end{array}$ \\
\hline \multirow{4}{*}{$\begin{array}{l}\text { Low } \\
(0 \%-60 \% \text { AMI })^{a}\end{array}$} & \multirow{2}{*}{$\begin{array}{l}\text { Single- } \\
\text { family }\end{array}$} & Owner-occupied & 10.01 & 4,521 & 11,330 \\
\hline & & Renter & 5.87 & 2,325 & 11,019 \\
\hline & \multirow[t]{2}{*}{ Multifamily } & Owner-occupied & 0.56 & 689 & 2,664 \\
\hline & & Renter & 9.65 & 4,607 & 6,431 \\
\hline \multirow{4}{*}{$\begin{array}{l}\text { Moderate } \\
(60 \%-120 \% \text { AMI })\end{array}$} & \multirow{2}{*}{$\begin{array}{l}\text { Single- } \\
\text { family }\end{array}$} & Owner-occupied & 8.37 & 3,853 & 12,035 \\
\hline & & Renter & 2.53 & 1,033 & 11,762 \\
\hline & \multirow[t]{2}{*}{ Multifamily } & Owner-occupied & 0.44 & 570 & 5,197 \\
\hline & & Renter & 4.35 & 2,120 & 6,968 \\
\hline \multirow{4}{*}{$\begin{array}{l}\text { High } \\
\text { (> 120\% AMI) }\end{array}$} & \multirow{2}{*}{$\begin{array}{l}\text { Single- } \\
\text { family }\end{array}$} & Owner-occupied & 40.20 & 18,665 & 13,609 \\
\hline & & Renter & 4.58 & 1,894 & 12,294 \\
\hline & \multirow[t]{2}{*}{ Multifamily } & Owner-occupied & 2.47 & 3,025 & 6,207 \\
\hline & & Renter & 9.08 & 4,219 & 6,795 \\
\hline
\end{tabular}

Source: REPLICA data ("Rooftop Energy Potential of Low Income Communities in America: REPLICA," NREL Data Catalog, https://data.nrel.gov/submissions/81)

$$
\mathrm{a}=\text { area median income }
$$

Suitable roof area in REPLICA was derived using lidar data of rooftops at $1 \mathrm{~m}^{2}$ resolution. Shading, tilt, and azimuth were assessed for each household to determine suitable roof size in each building (Sigrin and Mooney 2018; Gagnon et al. 2016). More than twice as much suitable roof space is available for high-income households $\left(27,803\right.$ million $\left.\mathrm{ft}^{2}\right)$ than low-income households (12,142 million $\mathrm{ft}^{2}$ ) (Table 3, Figure 1). The amount of suitable roof space for lowincome households is approximately the same in single-family owner-occupied buildings $(4,521$ million $\left.\mathrm{ft}^{2}\right)$ and multifamily renter-occupied buildings (3,853 million $\left.\mathrm{ft}^{2}\right)$. Most suitable roof space for high-income households is in single-family owner-occupied buildings $(18,665$ million $\mathrm{ft}^{2}$ ), which is more than four times as much suitable roof space in single-family owner-occupied buildings for low-income households (4,521 million $\left.\mathrm{ft}^{2}\right)$. Moderate-income households reside in buildings with the lowest amount of suitable roof space (7,576 million $\left.\mathrm{ft}^{2}\right)$. Additionally, across 
income groups, single-family owner-occupied have more than double the amount of suitable roof space $\left(27,039\right.$ million $\left.\mathrm{ft}^{2}\right)$ that multifamily renter-occupied buildings have $\left(10,946\right.$ million $\left.\mathrm{ft}^{2}\right)$. The suitable roof area for each income category and building type will drive the solar adoption results for each category in this analysis.

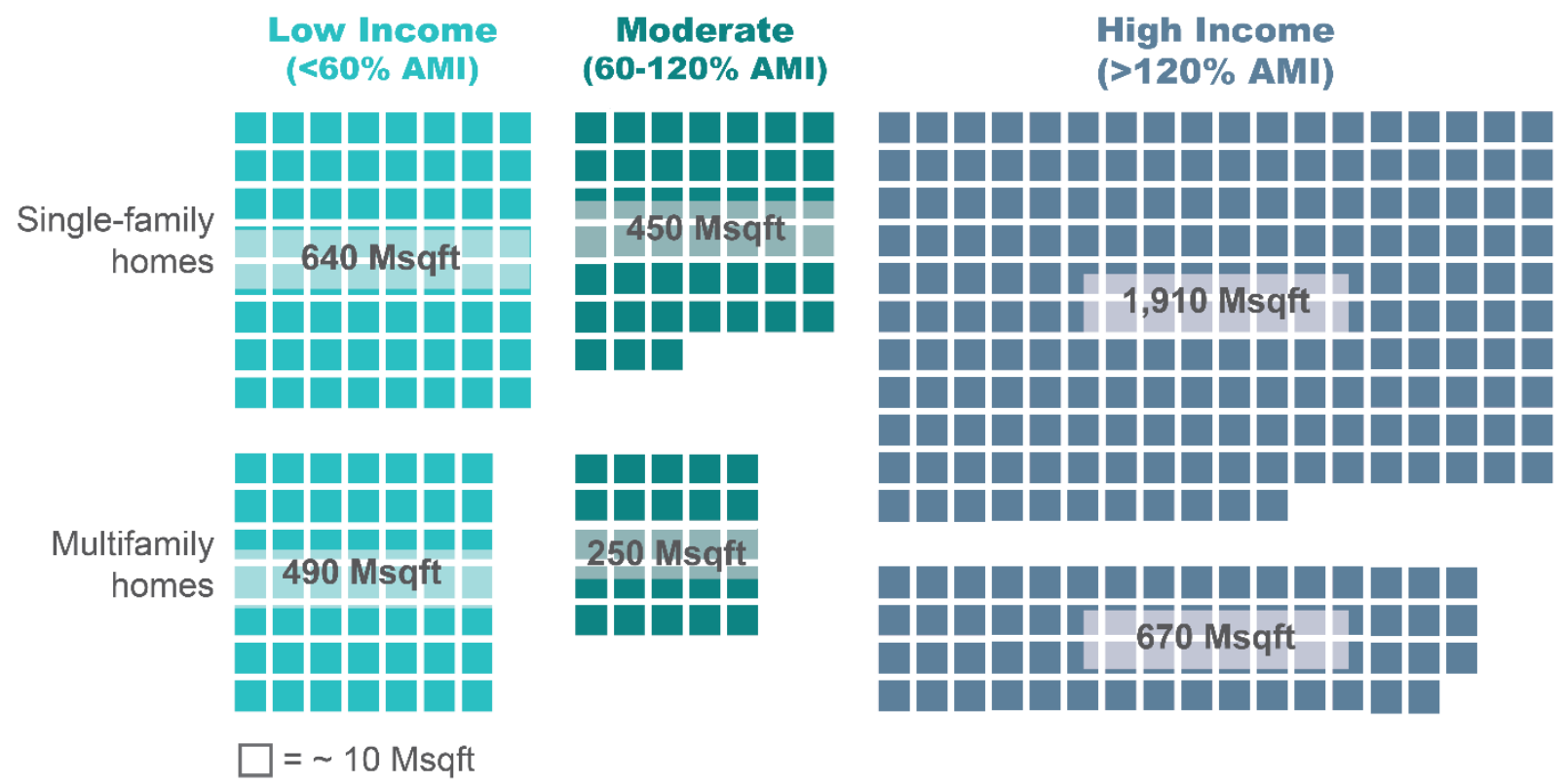

Figure 1. Modeled rooftop solar area by building tenure and occupant income

Msqft $=$ million square feet

\section{Discount Rates}

To differentiate consumer decision making between household types, we employed several strategies. First, we assigned appropriate discount rates to differentiate household types by the three income brackets we identified in Table 2. Currently, the dGen model uses the weighted average cost of capital from NREL's 2020 Annual Technology Baseline (ATB) (NREL 2020) as the discount rates for single-family owner-occupied households. To develop estimates of the weighted average cost of capital for our three income categories, we assumed the current discount rate represents a moderate income (60\%-120\% AMI) households, and we interpolated with discount rate by income decile data from Samwick (1998).

Second, we used discount rates to differentiate buildings owned by the tenant and those rented by the tenant. We create 1) multifamily owner-occupied agents that represent decisions akin to condominium owners (i.e. those who own their property) and 2) multifamily renter-occupied agents that represent decisions akin to renters. Though owners of the rental buildings are responsible for installing solar, their decision-making landscape is significantly different from 
that of household owners who live on their property. ${ }^{12}$ Though it cannot be directly reflected in the dGen model, we explored two approaches for representing the adoption of solar by renters:

- Increasing Discount Rates to Account for Ownership Frictions: For example, the dGen model optimizes system size based on the net present value of the system (increasing discount rates of renters) and decreases the size of the system (sometimes to zero when using large discount rate values), thereby indirectly reducing the penetration rate of renters.

- Derating the Relationship between Payback Period and Willingness to Adopt for Renters (i.e., Maximum Market Share): Adoption in dGen is based on a modified Bass model, where a variable named maximum market share constrains the number of adopters each year. Maximum market share is derived based on relationship payback period for PV in that year. Derating the relationship between payback period and maximum market share means for the same payback period the maximum market size of renters is set a lower value than that of owners.

First, we examined two scenarios: (1) we assumed renters behave the same as owners (i.e., split incentives and other barriers do not exist) and therefore used the same discount rate for both owners and renters, and (2) we assumed the split incentive problem persists in the future and therefore we assumed renters have a significantly higher discount rate $(100 \%)$ than owners to prevent rental units avoid installing solar PV. We also add a high discount rate variation scenario. Finally, we did not apply any discount rate differentiation between single-family and multifamily households. Table 4 summarizes our assumptions.

Table 4. Discount Rate Assumptions by Income Bracket and Tenure

\begin{tabular}{|l|l|c|c|}
\hline Income Class & Tenure & $\begin{array}{l}\text { Standard Discount } \\
\text { Rate Variation }\end{array}$ & $\begin{array}{l}\text { High Discount Rate } \\
\text { Variation }\end{array}$ \\
\hline Low income & $\begin{array}{l}\text { Renter (no split incentives) } \\
\text { and owner }\end{array}$ & $3.5 \%$ & $4 \%$ \\
\hline Moderate income & $\begin{array}{l}\text { Renter (no split incentives) } \\
\text { and owner }\end{array}$ & $3.1 \%$ & $1.8 \%$ \\
\hline High income & $\begin{array}{l}\text { Renter (no split incentives) } \\
\text { and owner }\end{array}$ & $2.5 \%$ & $100 \%$ \\
\hline All income levels & $\begin{array}{l}\text { Renter (full split } \\
\text { incentives) }\end{array}$ & $100 \%$ & \\
\hline
\end{tabular}

a All results presented in this analysis for owners use the standard discount rate variation case.

\section{Derating}

The discount rates in Table 4 provide the upper bounds of solar adoption when a building owner rents a residence and experiences a split incentive, which we refer to in the results as "solved" and "never resolved" respectively. Another method for reflecting the split incentive issue is to

\footnotetext{
${ }^{12}$ Generally, there are three scenarios for utility bill payment with multifamily buildings: (1) owners pay the utility bills, (2) utility bills are included in tenants' rent, and (3) tenants pay their own utility bills. In the last two scenarios, the owners may not have an incentive to make a capital investment in PV when the benefit (electric bill reduction) goes to the tenants. This issue has been described in the energy efficiency literature and now in the distributed solar adoption literature as the split incentive problem (Blumstein et al. 1980).
} 
derate the relationship between payback period and maximum market size for renters. In this approach, the relationship between the payback period and the renter's market share will be only $87 \%$ of the maximum market potential of the owners. In Nie et al. (2020) and Melvin (2018), split incentives resulted in 16\% lower adoption of energy efficiency measures and $10.6 \%$ lower adoption of distributed PV by property owners; we used these studies to represent an optimistic scenario, Partially Addressed, in which split incentives are partially addressed for renteroccupied buildings in the United States by derating the maximum market share of distributed PV for renters by $13 \%$ in this analysis. However, current adoption of solar by renter-occupied building owners is likely much lower and data could be collected to better characterize this market segment.

Because many low-income policies are programs are being developed at the state level, we developed agents by income-level and tenure and for each state. ${ }^{13}$ In addition to the differentiation by the discount rates outlined in Table 2, the suitable roof space and annual energy consumption from Table 1 also contribute to the differentiation between agents. Other attributes such as utility tariffs and the load profile of the households will be driven by data for each state but remain the same for all income- and tenure-based agents.

\section{Solar PV Prices}

Other Solar Futures Study reports explored how different solar price trajectories can impact solar deployment and achieve national goals. In this report, we also explored how solar prices might affect adoption trends for each income group, building type, and tenure. The two solar price scenarios we explored are from NREL's 2020 ATB Moderate and Advanced cases (Figure 2).

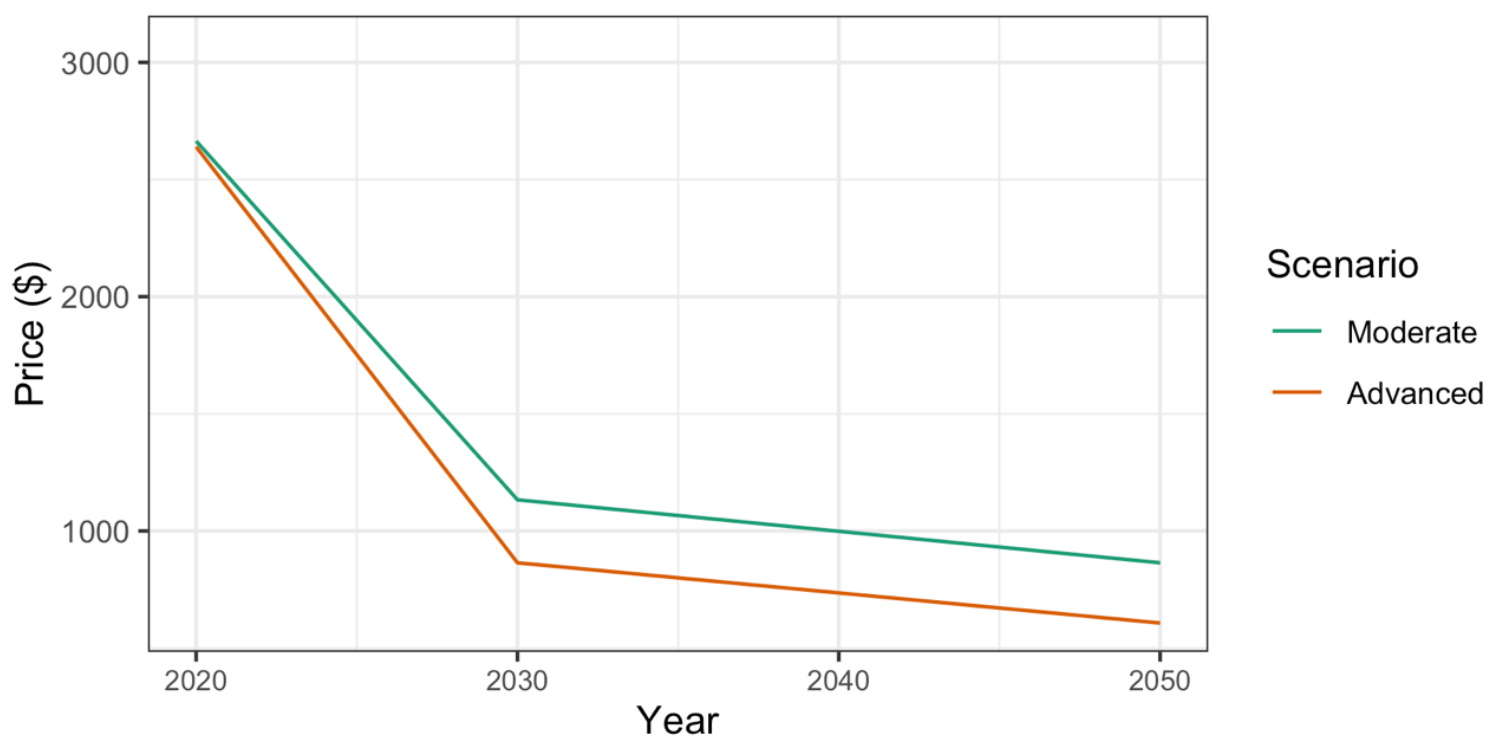

Figure 2. PV price scenarios in the Solar Futures Study (DOE 2021)

\footnotetext{
${ }^{13}$ The original dGen agents are sampled at the county-level, REPLICA provides data at the census-tract level, and we may be able to explore agents at the county or census-tract level in the future.
} 


\section{Incentives}

In addition to the business-as-usual scenario, we modeled two different investment-oriented incentives. First, we assumed a partial incentive of \$3,000 to LMI households on the capital cost to reflect the threshold for renewable energy investments by U.S. Department of Energy's Weatherization Assistance Program. ${ }^{14}$ To date, few states have been approved to use Weatherization Assistance Program funding to upgrade and weatherize low-income households with solar (Ulrich et al. 2018; Cook and Shah 2018). In this analysis, we considered the possibility of solar adoption and utility bill impacts if that incentive were available to all LMI households in the country. Second, we assumed a full incentive (i.e., the full capital cost is covered for LMI households). This full incentive was designed to reflect a few programs in the country that cover a substantial cost of a solar system for an income-qualified household; for example, California's Single-Family Affordable Solar Homes program provided \$3/W. ${ }^{15}$ The full incentive could also represent value that is provided through multiple sources, such as tax incentives, solar renewable energy certificates, or philanthropic funding.

\section{Limitations of the dGen Analysis}

Though we attempted to represent consumer decision making capabilities for different income groups and the split incentive issue for renters, these are still imperfect approaches to capturing a comprehensive set of financial and noneconomic barriers that LMI households face in adopting solar. In the scenarios for lower PV prices and incentives, we might not be explicitly addressing the other barriers and any adoption scenarios might be representing an upper bound of what might be possible if these barriers were also addressed, potentially through the game changers in Section 4. A more comprehensive consideration of the economic and noneconomic benefits and challenges of different solar access options - scale and business models - is needed. The energy efficiency customer adoption literature offers examples of empirical and econometric analysis that could be conducted to better isolate and quantitatively characterize economic and noneconomic barriers to adoption (Nie et al. 2020; Melvin 2018).

\subsection{Results}

In this section, we examine the potential impact of different solar prices and incentives on adoption by households of different income levels, building types, and tenure.

\section{Owners}

Single-family owner-occupied households adopted more solar overall than multifamily owneroccupied households (Figure 3). This is due in part to the difference in suitable roof space between single-family homes $\left(27\right.$ million $\mathrm{ft}^{2}$ ) and multifamily owner-occupied buildings ( 4 million $\mathrm{ft}^{2}$ ). However, there is still a tenfold difference in adoption per square foot of suitable roof space between single-family owner-occupied and multifamily owner-occupied buildings.

\footnotetext{
14 The U.S. Department of Energy's Weatherization Assistance Program specifies that expenditures for labor, materials and related matters cannot exceed \$3,000 subject to annual cost-of-living updates ("The Use of Solar PV in the WAP," WAP Memorandum 024, January 17, 2017, https://www.energy.gov/sites/prod/files/2017/01/f34/WAPMEMO\%20024\%201.17.17.pdf.

${ }^{15} \mathrm{https}$ ://www.cpuc.ca.gov/industries-and-topics/electrical-energy/demand-side-management/california-solarinitiative/csi-single-family-affordable-solar-homes-program
} 
Total energy consumption is also higher for single-family owner-occupied buildings ( $37 \mathrm{GWh}$ ) than multifamily owner-occupied buildings (14 GWh).
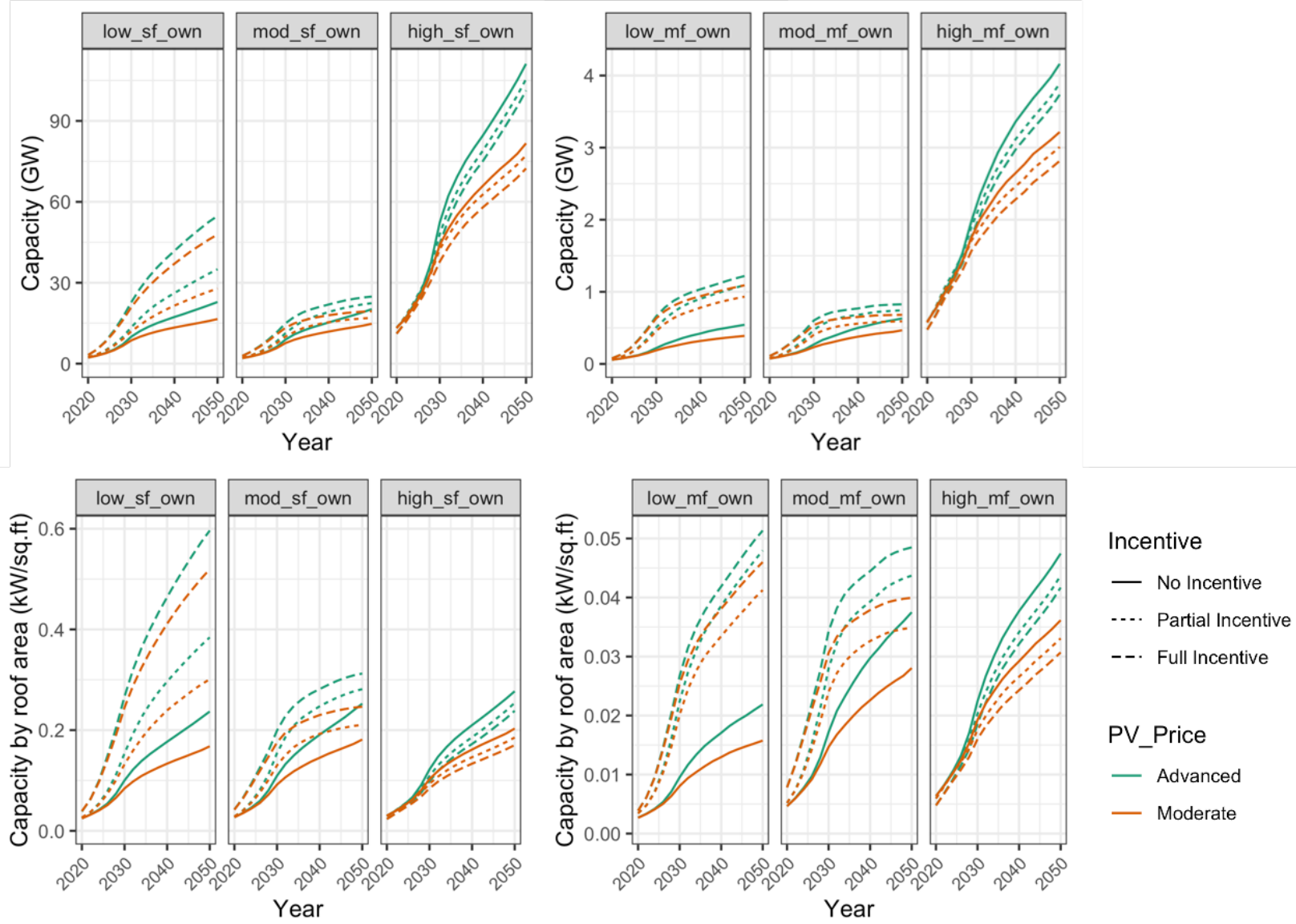

Figure 3. Solar adoption in owner-occupied buildings

\section{Single-Family Owners}

Lower prices led to increased adoption of solar across all income levels, with an increase in capacity for the Advanced PV price case by $5 \mathrm{GW}$ (low-income), $3 \mathrm{GW}$ (moderate-income), and $30 \mathrm{GW}$ (high-income). Lower prices had the most effect on the low-income and high-income groups. Though the difference in the level of adoption was driven by the available roof space for the high-income group, the growth in capacity by suitable roof area, was similar across income groups.

The incentives - a partial incentive of $\$ 3,000 /$ household and a full incentive that would cover the full price of the system - were only available to low- and moderate-income households. The impact of the incentives was most pronounced for the low-income households, as the incentives resulted in more than a doubling of customer adoption by 2050 from $22 \mathrm{GW}$ to $52 \mathrm{GW}$ with the Advanced PV prices, and a tripling of adoption from $15 \mathrm{GW}$ to $45 \mathrm{GW}$ with Moderate PV prices. The impact on moderate income single-family owners was much lower, increasing adoption by only $6 \mathrm{GW}$. Though the adoption per suitable roof space was approximately the same across income groups without the incentive, adoption per square foot was much higher in the low- 
income group with the full incentive and advanced prices $\left(0.6 \mathrm{~kW} / \mathrm{ft}^{2}\right)$ than in the moderate income group $\left(0.3 \mathrm{~kW} / \mathrm{ft}^{2}\right)$ and the high-income group $\left(0.25 \mathrm{~kW} / \mathrm{ft}^{2}\right)$.

\section{Multifamily Owners}

Again, the impact by 2050 of lower PV prices was much more pronounced in the high-income group without any new incentives, with an increase in capacity for the ATB Advanced PV price case by $0.15 \mathrm{GW}$ in the low-income and moderate-income groups compared to an increase of $1 \mathrm{GW}$ installed capacity in the high-income group due to the decrease in PV prices. However, there was a progressive increase in the adoption of solar given the suitable roof space as incomelevels increased for multifamily owners.

When the partial and full incentives were offered to multifamily low- and moderate-income owners, they had more impact on the low-income multifamily owners than the moderate-income group on a purely capacity basis. When accounting for the available roof space for solar, the levels of adoption per available roof area were comparable in the low-income and moderateincome groups, but the jump in adoption between the No Incentive and the Incentive cases was more pronounced for low-income than for moderate-income multifamily owners.

We also differentiated the discount rates of each income level but found that this variable did not have much impact on representing the financial barriers that lower income groups face with respect to adopting solar.

\section{Renters, Split Incentive}

Next, we considered how the split incentive affects solar adoption of renters in both singlefamily and multifamily buildings. The Solved and Never Resolved scenarios provide bookends for the solar adoption potential for renters. In the Solved scenario, we assumed the split incentive issue no longer exists because of new policies, programs, metering, or other solutions. Thus, renters adopt with the same discount rate as their owner counterparts. In the Never Resolved scenario, we assumed split incentives result in very little adoption, and in the Partially Addressed scenario, we assumed the split incentive issue improves substantially, but the maximum market share remains lower for renters than for owners. 

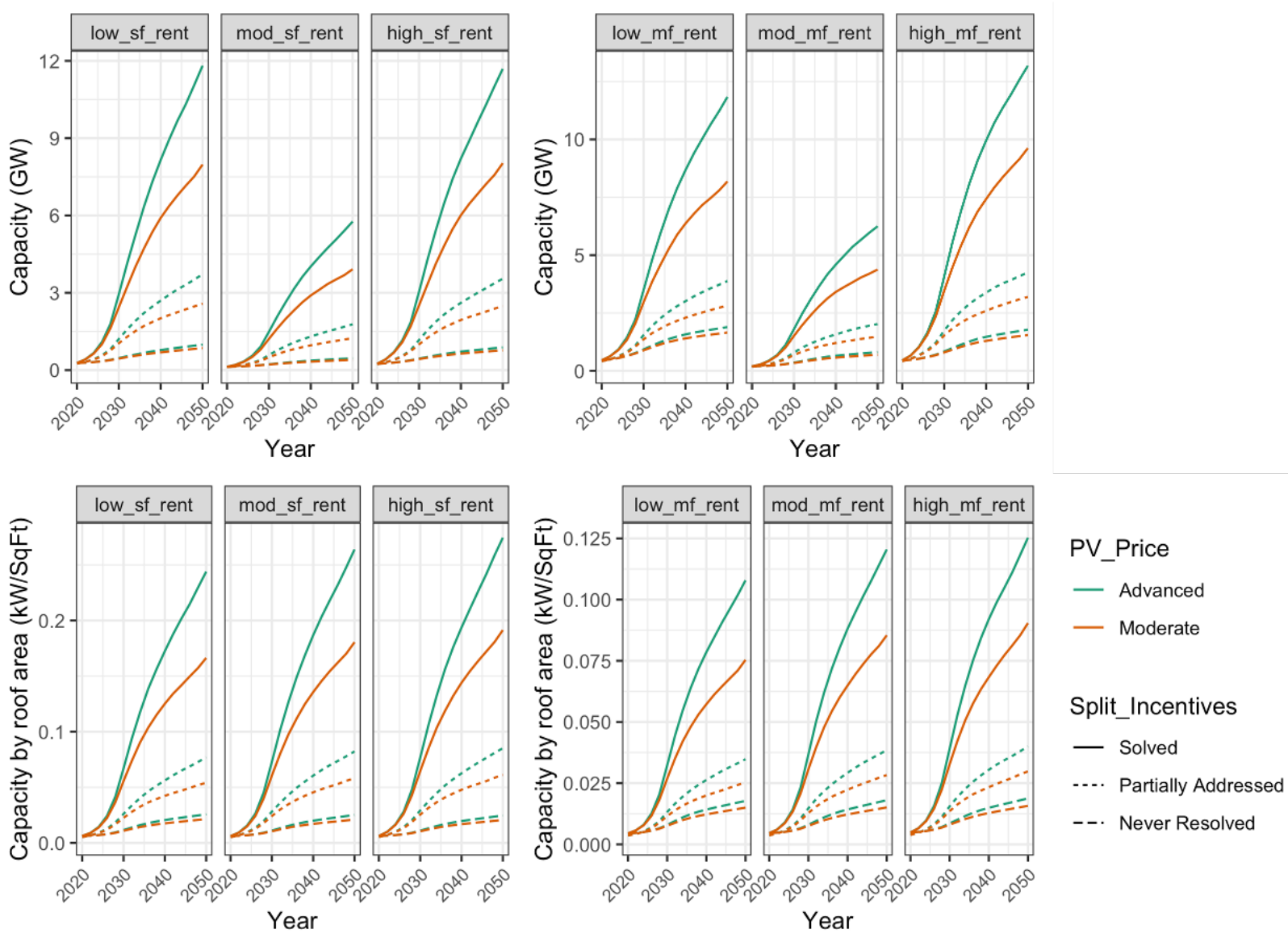

Figure 4. Solar adoption in renter-occupied buildings

When we assumed the split incentive issue was addressed, solar adoption was tenfold higher for low-income multifamily renters $(12 \mathrm{GW})$ than low-income multifamily owners (1.2 GW) (Figure 4). This is due in part to the suitable roof space for low-income multifamily renter-occupied buildings is more than double that available for multifamily owner-occupied buildings (Table 3).

For all renters, lower PV prices did not have much effect on the Never Resolved scenario in which the split incentive resulted in very low adoption overall. Lower prices did result in a similar increase in adoption within all income levels across the other split incentive scenarios. Low-income and high-income renters seem to have a higher level of adoption than moderateincome renters in both single-family and multifamily buildings, especially as the split incentives were addressed. That might be because suitable roof space for both low-income (6,932 million $\left.\mathrm{ft}^{2}\right)$ and high-income $\left(6,113\right.$ million $\left.\mathrm{ft}^{2}\right)$ renters is approximately double that available to moderate-income renters $\left(3,153\right.$ million $\left.\mathrm{ft}^{2}\right)$. When adoption was normalized against the suitable roof space, the capacity by roof area was very similar by PV price and split incentive scenarios across all income levels for single-family renters and also across multifamily renters.

\section{Renters, Incentives}

We then applied the partial incentive ( $\$ 3,000$ per household) and the full incentive to renters under the Moderate PV price, and we explored how that affected adoption under different split 
incentive scenarios (Figure 5). In these scenarios, both the partial and full incentives did encourage more adoption in the Never Resolved scenarios for both single-family and multifamily low-income renters. For low-income single-family and multifamily renters, the full incentive brought the adoption levels for the Never Resolved split incentive scenario up to the same level of adoption ( $\sim 7.5 \mathrm{GW}$ of capacity by 2050$)$ as when the split incentive issue was addressed in the Solved case without any incentives.
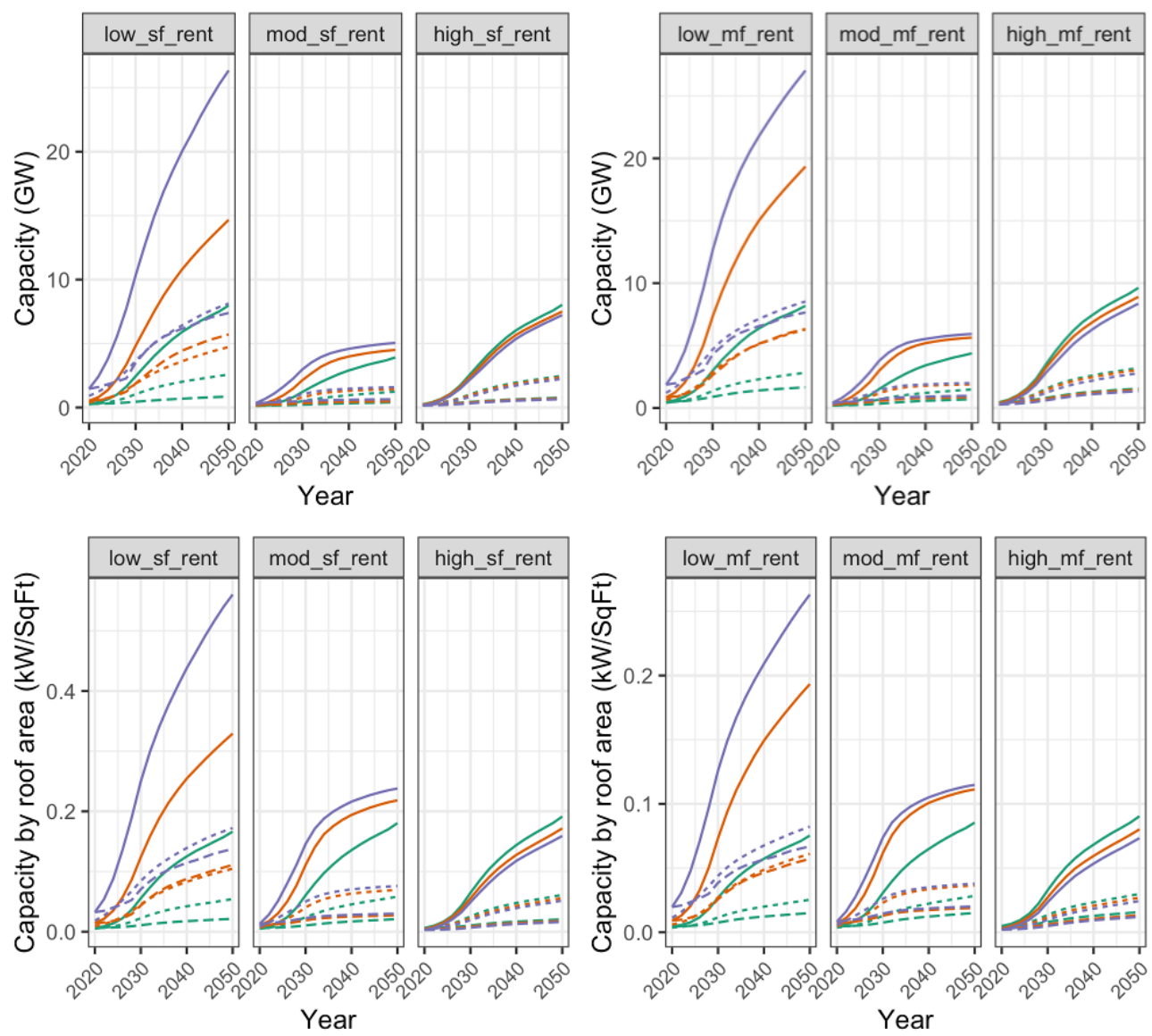

Incentive

- No Incentive

- Partial Incentive

— Full Incentive

Split_Incentives

- Solved

-... Partially Addressed

--. Never Resolved

Figure 5. Impact of incentives and split incentives on solar adoption by renters

The impact of the incentives on adoption did not seem to be as linked to the suitable roof space as the other factors (e.g., prices or split incentives). The incentives did seem to have a similar impact on low-income single-family adoption for renters as they did on owners, with the partial incentive for renters $(15 \mathrm{GW})$ increasing adoption twofold from the case with no incentive (7.5 $\mathrm{GW})$ and over threefold with the full incentive $(26 \mathrm{GW})$ by 2050 . We saw a similar impact with multifamily low-income renters with the partial incentive having a slightly higher impact on adoption than with single-family renters, with a difference of about $5 \mathrm{GW}$ of adoption by 2050 . The full incentive and no incentive cases resulted in very similar levels of adoption for the multifamily renters as single-family renters. Additionally, we might be able to achieve similar levels of adoption for low-income renters by either addressing the split incentives issue or providing a full incentive. 


\section{First Year Bill Savings}

First-year utility bill savings are generally higher for single-family owners (Figure 6), regardless of income class and incentive structure, than for multi-family owners or renters of either type. Savings for single-family owners range from $\$ 525$ to $\$ 870$ and may be a function of this group having the highest suitable roof space. The lowest first-year bill savings, which occurred mostly with both single-family and multifamily renters, ranged as low as $\$ 40-\$ 50$ in average first-year bill savings, except when a full incentive was offered. Both incentives had the most impact on first-year bill savings for all low-income households. The full incentive brought up the lower range of the first-year bill savings for low-income single-family owners by $\$ 135$, low-income single-family renters by $\$ 460$, and low-income multifamily renters by $\$ 315$ as compared to the scenarios without any additional incentives. The full incentive also increased the top range of all first-year bill savings by $\$ 20-\$ 110$ from the scenario with no incentives. The incentives impacted the lowest first-year bill savings for low-income multifamily renters, from $\$ 45$ (no incentive), $\$ 160$ (partial incentive), and $\$ 360$ (full incentive). The full incentive had the most impact on low-income single-family owners, increasing the range of first-year bill savings from $\$ 525-\$ 725$ (no incentive) to $\$ 660-\$ 805$ (full incentive).

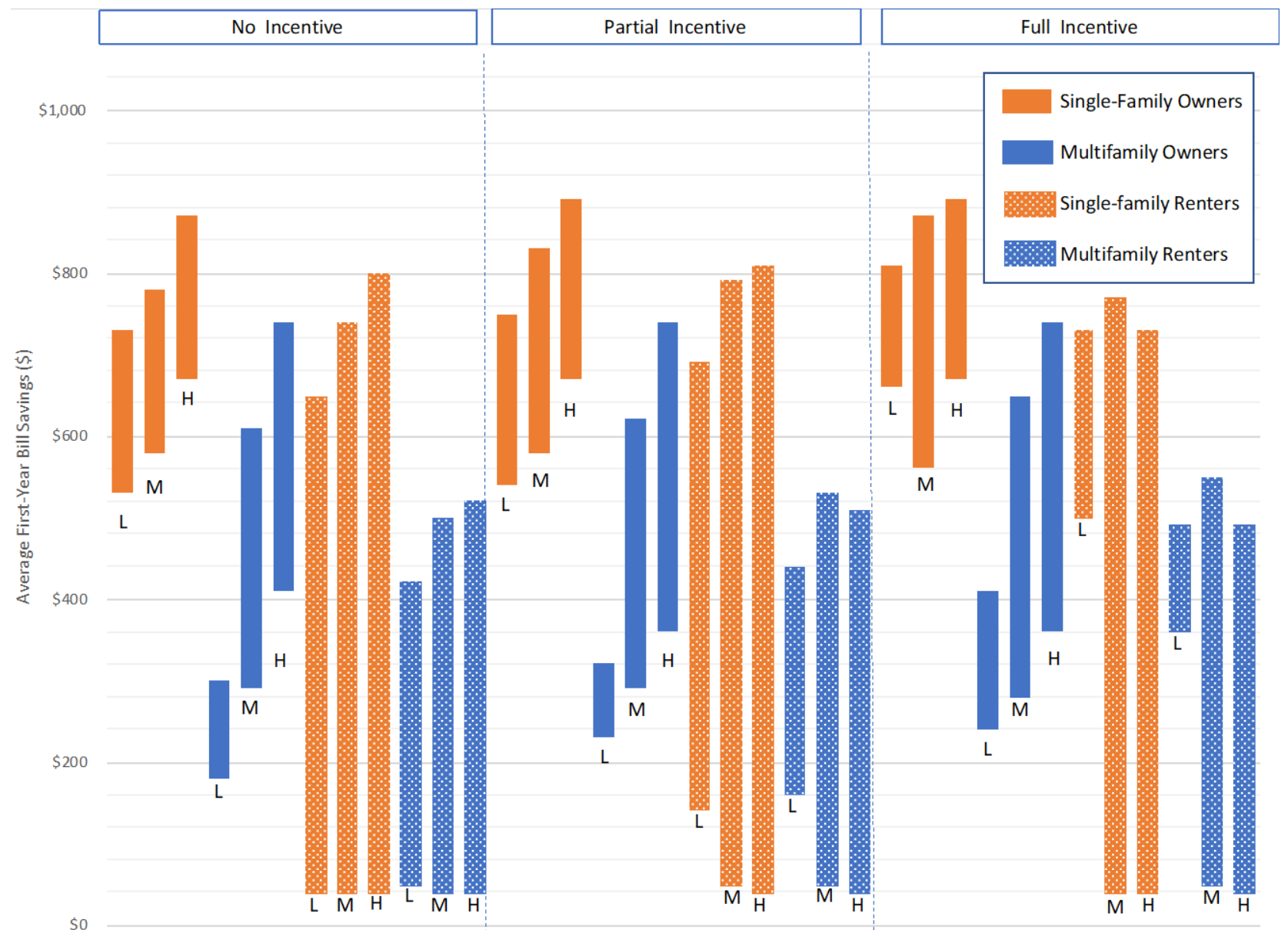

Figure 6. Range of average first-year gross bill savings for each market segment, between 2020 and 2050, all scenarios (ATB Moderate Prices and Partially Addressed split incentives) 


\section{Energy Burden}

We also calculated the energy burden, or the portion of a household's income that goes toward energy expenditures, for each of the scenarios. We compared the average change in energy burden for each state from the scenario with no incentives. The partial incentive resulted in energy burden reductions from $0.2 \%$ to $42.6 \%$, compared to no incentives, and half of the states had a change in energy burden above the average of all states (Figure 7). The average energy burden reduction was $17.8 \%$. Utah, Wisconsin, and Delaware experienced the largest reductions in average energy burden for LMI households in 2050.

With a full incentive, households installed larger PV system sizes than in the partial incentive scenario, thus providing greater reductions in energy burden than the partial incentive (Figure 7). Reductions in energy burden ranged from $8.6 \%$ to $81.2 \%$, and the average reduction in energy burden jumped from $17.8 \%$ from the partial incentive scenario to $26.3 \%$ in the full incentive scenario. Twenty-one states had an average reduction in energy burden above 26.3\%; Colorado, Delaware, Ohio, Wisconsin, and Utah had more than $40 \%$ reductions in energy burden with the full incentive by 2050. The full incentive increased the reduction in energy burden by at least 1.5 times for over half the states when compared to the change in energy burden with the partial incentive.

Partial Incentive

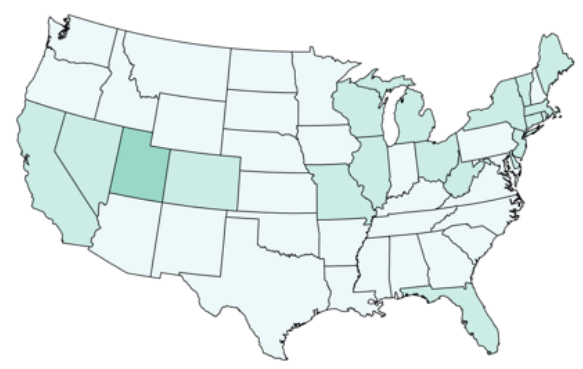

Full Incentive

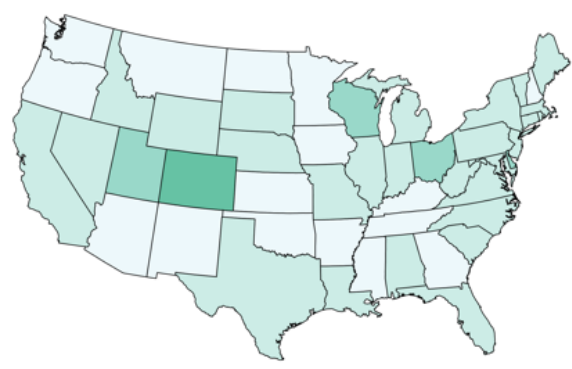

$\%$ Change in Energy Burden from the BAU scenario

$-20 \%$ to $0 \%$

$-40 \%$ to $-20 \%$

$-60 \%$ to $-40 \%$

$-100 \%$ to $-80 \%$

Figure 7. Percentage change in average LMI household energy burden when installing PV (2050)

$$
\mathrm{BAU}=\text { business as usual }
$$

Lastly, we examined the overall impacts of the incentives on adoption of solar by low- and moderate-income households and what total funding might be needed to provide these incentives. With the partial incentive, $51 \%$ more cumulative capacity of distributed solar systems were installed for low- and moderate-income households as compared to the scenario with no incentive and $122 \%$ more cumulative capacity when offered a full incentive.

In the scenarios with the partial incentive, $\$ 43$ billion on incentives was spent between 2020 and 2050, resulting in 14.7 million low-and moderate-income households adopting solar across the country over the 30-year time-frame, compared to only 8.8 million LMI households when no incentive was offered. ${ }^{16}$

\footnotetext{
${ }^{16}$ In the cases where the system cost was less than $\$ 3,000$, only the balance was allocated thereby constraining households to select small system size.
} 
However, when offered a full incentive, $\$ 127$ billion on incentives was spent between 2020 and 2050 to provide 15.3 million low- and moderate-income households across the country solar between 2020 and 2050. When offered a full incentive, households chose to build a larger system (on average $4.9 \mathrm{~kW}$ ) than when offered a partial incentive (on average $3.9 \mathrm{~kW}$ ). See Table $5 .{ }^{17}$

Table 5. Cumulative Results of the Incentives Scenarios on Low- and Moderate-Income Households between 2020 and 2050 (Partially Addressed Split Incentive, Moderate PV Price)

\begin{tabular}{|l|l|l|l|l|l|l|}
\hline $\begin{array}{l}\text { Incentive } \\
\text { Level }\end{array}$ & $\begin{array}{l}\text { Cumulative } \\
\text { Capacity } \\
\text { Installed } \\
\text { Households } \\
\text { (GW) }\end{array}$ & $\begin{array}{l}\text { Adopters } \\
\text { (million } \\
\text { households) }\end{array}$ & $\begin{array}{l}\text { Ave. } \\
\text { System } \\
\text { Size (kW) }\end{array}$ & $\begin{array}{l}\text { Total } \\
\text { Investment } \\
\text { in Solar } \\
\text { (\$ billion) }\end{array}$ & $\begin{array}{l}\text { Total } \\
\text { Incentives } \\
\text { Provided } \\
\text { (\$ billion) }\end{array}$ & $\begin{array}{l}\text { Total Net } \\
\text { First-Year } \\
\text { Bill Savings } \\
\text { (\$ billion) }\end{array}$ \\
\hline $\begin{array}{l}\text { No } \\
\text { incentive }\end{array}$ & 41 & 8.8 & 3.8 & 47 & 0 & 30 \\
\hline $\begin{array}{l}\text { Partial } \\
\text { Incentive } \\
(\$ 3,000)\end{array}$ & 62 & 14.7 & 3.9 & 87 & 43 & 69 \\
\hline $\begin{array}{l}\text { Full } \\
\text { Incentive }\end{array}$ & 91 & 15.3 & 4.9 & 127 & 127 & 101 \\
\hline
\end{tabular}

Note: Total investment includes the cost of the incentives provided as well as the remaining cost of the solar system, if applicable.

Though the larger incentive did increase the number of LMI households adopting solar, the impact on system size was greater than that on the number of household adopters (Table 5); this is because the Bass model constrains future adoption based on system capacity and not number of households. Furthermore, once a threshold level of adoption is reached, the net metering benefit expires, making it less financially attractive for some households to adopt solar.

If the incentives were allocated evenly over the 30-year time-frame of 2020-2050, approximately $\$ 2.1$ billion- $\$ 3.4$ billion would be spent annually, depending on whether a full or partial incentive is provided. ${ }^{18}$ This level of support is of a similar magnitude to that collectively spent by U.S. Department of Energy's Weatherization Assistance Program, the U.S. Department of Health and Human Services on the Low-Income Energy Assistance and Heating Program, and the U.S. Department of Housing and Urban Development on energy assistance and crisis programs annually (Mueller and Ronen 2015; Paulos 2017). This level of funding could provide $48 \%-49 \%$ of LMI households with solar systems, resulting in $\$ 69$ billion-\$101 billion in total net first-year utility bill savings for LMI households. And there would likely be additional utility bill savings for LMI households over the full project life (e.g., 20-25 years) for a solar system.

\footnotetext{
${ }^{17}$ The average system sizes did not differ much when households were offered a partial incentive $-3.6 \mathrm{~kW}$ with no incentive to $3.9 \mathrm{~kW}$ with an incentive - but they did increase to $4.9 \mathrm{~kW}$ when offered a full incentive.

${ }^{18}$ This assumes the ATB Moderate PV price and that split incentives are substantially improved in the Partially Addressed scenario for renters.
} 


\section{Transforming Low- and Moderate-Income Solar Adoption?}

In modeling our scenarios, we used informed judgement about what changes could occur to enable low-income adoption of onsite PV generation. In this section, we discuss on-the-ground methods for achieving those outcomes. We also discuss how other solar options, such as community solar, can enable greater solar access and affordability. We do not touch on the broader societal transformations that could occur, for example, addressing barriers to lowincome individuals owning their own homes or broader efforts to mitigate income disparity. Certainly, such transformations would impact the ability of low-income individuals to receive benefits from solar.

\subsection{Pathways to Expanding LMI Solar Adoption}

Solutions to enable low-income adoption of onsite PV generation need be able to both scale and provide automatic access to low-income customers. Table 6 frames the solution space in terms of short term (2035) and long term, transformative change (2050 and beyond), building on the barriers identified in Section 2. Many of the solutions touch on multiple barriers but are placed in one category here for the sake of simplicity.

Table 6. Short- and Long-Term Solutions to LMI Solar Adoption Barriers

\begin{tabular}{|c|c|c|}
\hline & Short Term (2035) & Long Term (2050+) \\
\hline $\begin{array}{l}\text { Finance and } \\
\text { funding }\end{array}$ & $\begin{array}{l}\text { - Enabling of solar leasing and other zero- } \\
\text { down solar products, such as community } \\
\text { solar } \\
\text { - Increase in utility, state, and federal } \\
\text { dollars toward low-income solar } \\
\text { deployment } \\
\text { - Wide-spread adoption of alternative } \\
\text { underwriting criteria (e.g., Solstice } \\
\text { Initiative's EnergyScore) rather than } \\
\text { consumers' credit scores }\end{array}$ & $\begin{array}{l}\text { - Automatic enrollment of low- } \\
\text { income customers in a solar } \\
\text { option that is designed with their } \\
\text { input (either on-site or off-site) } \\
\text { and provides a utility bill } \\
\text { reduction from day one } \\
\text { - Application of funding sources } \\
\text { for low-income energy } \\
\text { assistance programs to solar, } \\
\text { providing savings on a long-term } \\
\text { basis }\end{array}$ \\
\hline $\begin{array}{l}\text { Community } \\
\text { engagement }\end{array}$ & $\begin{array}{l}\text { - Collaboration of solar industry, including } \\
\text { policymakers and project developers, } \\
\text { with community organizations to } \\
\text { implement new pilot programs by } \\
\text { building expertise within those } \\
\text { organizations and providing technical } \\
\text { assistance } \\
\text { - School-based events to educate children } \\
\text { on solar; continued outreach efforts at } \\
\text { events, seminars, and open forums in } \\
\text { LMl communities } \\
\text { - Implementation of strategies of strategies } \\
\text { by utilities, regulators, and others to } \\
\text { gather input on solar policies and }\end{array}$ & $\begin{array}{l}\text { Meaningful roles are filled by } \\
\text { community organizations in } \\
\text { creating low-income solar } \\
\text { options } \\
\text { - Community organizations and } \\
\text { other organizations have optimal } \\
\text { ways to use solar as a wealth } \\
\text { building strategy for low-income } \\
\text { communities }\end{array}$ \\
\hline
\end{tabular}




\begin{tabular}{|c|c|c|}
\hline & Short Term (2035) & Long Term (2050+) \\
\hline & $\begin{array}{l}\text { programs from LMI consumers and those } \\
\text { who serve them }\end{array}$ & \\
\hline Site suitability & $\begin{array}{l}\text { - Increase in programs by utility, state, and } \\
\text { federal agencies that combine solar with } \\
\text { multiple other service delivery options } \\
\text { - Ability to use solar funding mechanisms } \\
\text { for ancillary needs (e.g., roof repair or } \\
\text { replacement, and electric wiring updates) }\end{array}$ & $\begin{array}{l}\text { - Comprehensive service delivery } \\
\text { of all low-income services } \\
\text { - Off-site solar options designed } \\
\text { with low-income input provided } \\
\text { on a default basis to low-income } \\
\text { households }\end{array}$ \\
\hline $\begin{array}{l}\text { Policy and } \\
\text { regulation }\end{array}$ & $\begin{array}{l}\text { - Increase in interest by states and/or } \\
\text { federal government in including low- } \\
\text { income access mandates for on-site and } \\
\text { off-site solar programs, with funding and } \\
\text { incentives to support the mandates } \\
\text { - States enabling off-site solar options and } \\
\text { ensuring robust consumer protections } \\
\text { - States ensuring against adverse effects } \\
\text { of energy policies on LMI households. } \\
\text { - Providing households and communities } \\
\text { access full suite of incentives and ability } \\
\text { to retain solar savings, including those in } \\
\text { tribal or federally assisted housing }\end{array}$ & $\begin{array}{l}\text { Requirements for solar (on-site } \\
\text { or off-site) on all buildings } \\
\text { serving low-income populations } \\
\text { - Utility regulation modified to align } \\
\text { the natural incentives of solar } \\
\text { developers, low-income building } \\
\text { owners, and tenants, for } \\
\text { example via performance-based } \\
\text { regulation or utility business } \\
\text { model transformation }\end{array}$ \\
\hline $\begin{array}{l}\text { Resilience and } \\
\text { Recovery }\end{array}$ & $\begin{array}{l}\text { Development of pilot technology projects } \\
\text { that provide community resilience } \\
\text { capabilities and allow low-income } \\
\text { buildings to both be grid assets and } \\
\text { provide community resilience } \\
\text { - Increased efforts by stakeholders to } \\
\text { ensure federal pre- and post-disaster } \\
\text { funding is more readily available and } \\
\text { used by low-income households }\end{array}$ & $\begin{array}{l}\text { Pre- and post- disaster funding } \\
\text { used more by low-income } \\
\text { households than non-low-income } \\
\text { households }\end{array}$ \\
\hline
\end{tabular}

\subsubsection{Finance and Funding}

Implementing financing mechanisms that provide easier access to capital, or which require consumers to provide minimal or no capital outlay, can expand solar access to low-income customers. Low-income solar adopters likely need little to no up-front cost to adopt solar. Several short- and long-term solutions have been explored to address financing and funding barriers.

\section{Enabling Solar Leasing and Other Zero-Down Solar Products}

O'Shaughnessy et al. (2021) found that for on-site PV systems, the presence of solar leasing created more equitable adoption of solar, and the addition of leasing resulted in a reduction in adopter income bias. Other solar options, such as community solar, can mitigate the need for individuals to secure their own financing for a solar investment while still providing bill credits to low-income customers. Community solar developers have developed shorter-term contracts that do not require subscribers to have their credit checked or provide an upfront investment. 


\section{State, Federal, or Other Funding}

The existing landscape of LMI solar funding has focused on state-level activities, but it certainly could be expanded from the 21 states and Washington, D.C., that currently have low-income solar programs (including community solar, single-family, and multifamily home programs, programs targeting organizations that serve low-income clientele, and programs targeting historically disadvantaged communities or communities where environmental justice is a concern (Stanton 2020)). At the federal level, a direct pay option for the investment tax credit—for either for all solar projects or only those that provide benefits to low-income consumers-would provide funding to customers who do not have a tax appetite (Bolinger 2014).

Other grant, rebate, loan, and financing options have been proposed to enable low-income solar adoption. For example, the Affordable Solar Energy for Our Communities Act passed the House in 2020, and if enacted would provide $\$ 200$ million of funding for grants, rebates, and lowinterest loans specifically benefiting low-income homeowners, nonprofits that serve low-income households, and multifamily affordable housing complexes. ${ }^{19}$ Another similarly focused bill has also been introduced, the Clean Energy and Sustainability Accelerator Act, which could provide financing to eligible regional, state, and local green banks, and which could make direct investments in renewable energy projects. ${ }^{20}$ The U.S. Department of Housing and Urban Development and the U.S. Department of Agriculture can also directly fund solar deployment.

At the state level and local levels, governments adjust or develop new programs targeted to lowincome adopters. This could be done at the household level (e.g., providing an added incentive for low-income households to install solar), community solar level (e.g., providing an added incentive for community solar projects that subscribe low-income households as is done in Massachusetts), or the utility-scale level (e.g., providing automatic enrollment for low-income households in its cost-saving community solar program as is done Imperial Irrigation District in California). To fund these programs states and utilities could draw from existing energy-related funding. For example, California has used revenue from its cap-and-trade program to fund lowincome community solar projects in the state. Funding opportunities are not limited to government activity; for example, philanthropic foundations could use grants and investments to support low-income solar adoption directly or indirectly (Sanders and Milford 2017).

Utilities could also create customer programs targeted at low-income solar adoption. Using funding typically reserved for bill-repayment, or other sources, utilities could provide funding for installations on low-income single-family homes.

Using pre-and post-disaster recovery dollars to invest in solar could be another funding strategy. Analyses show that low-income communities are subject to worse national disaster effects based on their location (Hallegatte et al. 2016; Ross 2013; Lee 2018). And housing assistance after extreme weather events often favors middle-class victims, particularly homeowners (Pastor et al. 2006).

\footnotetext{
19 "H.R.8165: Affordable Solar Energy for Our Communities Act," 116th Congress (2019-2020), https://www.congress.gov/bill/116th-congress/house-bill/8165? r=2\&s=1.

20 "H.R.806: Clean Energy and Sustainability Accelerator Act," 117th Congress (2021-2022), https://www.congress.gov/bill/117th-congress/house-bill/806.
} 


\section{Changes in Credit Agreements}

Changes in credit agreements could also promote more equitable access. For example, innovating financing programs that address barriers such as long-term contract requirements, nontransferable solar subscriptions, low credit, and seasonal income fluctuations are being investigated by NREL and others via funding from the U.S. Department of Energy (DOE SETO 2020).

In the longer term, eliminating the need for low-income customers to finance their systems would provide a streamlined way for low-income customers to access the cost-savings of solar energy. Access could be provided via on-site options (e.g., a utility or third-party-owned system) or off-site options (e.g., automatic enrollment in a community solar or utility solar program). Funding for low-income energy assistance programs could be applied to solar first, providing savings on a long-term basis.

\section{Aligning Financial Incentives}

Alignment of utility and other business incentives could provide greater investment in lowincome solar. This could be accomplished, for example, through a refundable investment tax credit or through utility-specific reforms that tie a state's low-income objectives to utility performance metrics. For example, in Hawaii, regulators have adopted performance-based regulation framework that includes a focus on customer equity and affordability (Hawaii Public Utilities Commission 2020).

\subsubsection{Community Engagement}

Several short- and long-term solutions have been explored to address the limited community engagement that has happened to date in LMI communities.

\section{Education and Outreach Efforts}

Community organizations have begun working with solar developers to implement pilot programs. In the longer term, community organizations need to become more familiar with solar projects and incorporate them into the possible solution set to improve lives of LMI residents. Because community organizations are time- and budget-constrained, they rely on others to provide the capacity, technical assistance, and financial assistance. Solar developers can partner with and financially support community-based organizations addressing the information and trust gaps within their communities regarding energy and solar. Such expanded efforts to educate LMI communities could include events, seminars, and open forums to enable a greater trust and understanding for solar technologies, as well as increased solar adoption (Ramanan et al. 2021).

\section{Participatory Processes}

Most citizens and smaller community organization have difficulty participate in utility processes and proceeding. Because of their time-consuming, often expensive, and technical nature, these proceedings limit the input from people and organizations in the best position to understand what LMI communities need. Holding meetings in LMI communities and providing transportation or childcare can reduce some of the barriers that often keep important stakeholders from participating. Utilities, regulators, and others could also create more-inclusive processes by, for example, providing a stipend to be involved in these processes, taking surveys, funding capacity- 
building and training, or hiring a third party facilitator to help explain difficult issues in everyday language (Ramanan et al. 2021).

\section{Wealth Creation}

Community engagement encompasses not only participatory, inclusive processes but also the ability to create new ways to create wealth in communities. Renewable energy technologies are more capital-intensive than other generation sources, meaning they disproportionately benefit the investment class. Some communities may want to take a more active role in investing in renewable energy technologies so they can receive the benefits of owning the technologies. Some emerging models prioritize community development, control, and ownership of solar systems and programs, such as by providing technical assistance and raising incentive levels for project development by community-based nonprofits or cooperatives (Baker 2021). Also, solar incentives for LMI and underserved communities can be combined with worker protections, local job training, and entrepreneurship support targeting underrepresented populations.

\subsubsection{Site Suitability}

Solutions involving providing funding for improving housing stock exist and can address the barrier of site suitability, as can solutions offering off-site solar options, which do not require housing improvements to be made. Several short- and long-term solutions have been explored to address site suitability barriers.

\section{Funding for Housing Stock Improvements}

Programs that provide funding for ancillary efforts to support installation, such as rooftop replacement or electrical panel upgrades, could significantly expand the number of eligible homes owned or occupied by LMI households and could reduce drop-off rates among otherwise interested households.

\section{Integrated Service Delivery}

In the future, low-income adoption could be accelerated by integrating solar installation with other low-income services. These services could be energy-related, such as weatherization efforts, or more broadly focused on other low-income housing services or other benefits, such as the Supplemental Nutrition Assistance Program and the Temporary Assistance for Needy Families program. Packaging solar with other service delivery options can provide additional savings for tenants and streamline the customer adoption process. Service delivery of on-site solar via the U.S. Department of Energy's Weatherization Assistance Program has been demonstrated, and renewable energy is considered a weatherization measure; the December 2020 Stimulus Bill provides $\$ 1.7$ billion for the Weatherization Assistance Program and formally considers renewable energy installations as eligible weatherization measures (Morehouse 2020).

\section{Off-Site Solar Options}

The primary workaround for unsuitable buildings is to source the solar from off-site projects. Providing off-site solar directly to households could deliver bill savings. However, one challenge to sourcing from off-site solar projects is that the program might miss the added benefit of integrated service delivery, for example, if homes are automatically enrolled in a new off-site solar program but no visit to the home is conducted and no additional weatherization or other services are offered. 


\subsubsection{Other Policy and Regulation Solutions}

Many barriers could be addressed through policy and regulation reforms. To address the policy and regulation barriers, several short- and long-term solutions have been explored.

\section{Eliminating the Landlord-Tenant Split Incentive Problem}

Though landlord-tenant issues are not unique to low-income individuals, they disproportionately effect the ability of low-income tenants to have access to on-site solar. Solutions for delivering energy efficiency and solar in light of split incentives have been proposed, including on-bill financing options, green leases, and building standards (Bird and Hernández 2012; Hynek, Levy, and Smith 2012). Solutions could also include incentives or mandates for including solar on new construction or as a condition of receiving or retaining federal assistance, as well as off-site solar solutions.

Federal rules can exacerbate the split incentive problem. In some federally assisted housing facilities, "utility allowance" calculations combine rent and utility payments to determine a cost cap paid by tenants; households do not retain reductions in utility payments from solar because they are counterbalanced by subsequent increases in rent under the allowance. This issue has been resolved by the U.S. Department of Housing and Urban Development for California's Solar on Multifamily Affordable Housing program, ${ }^{21}$ and legislation or rulemaking could expand the retention of solar savings to households receiving federal housing assistance nationwide.

In our dGen modeling work, we provide three split incentive scenarios to highlight the uncertainty in whether, how fast, and to what degree this issue could be resolved through 2050:

- State Policies for Solar Access: States, in crafting renewable portfolio standards or clean energy standards, community solar programs, or building standards, could specify a percentage of program funding, capacity, or another metric dedicated to low-income solar access. For example, in New Jersey, the community solar pilot program was required to include a $40 \%$ carve-out for projects serving at least 51\% LMI customers (Stanton 2020). States could also create non-income specific access mandates, such as building standards that require solar for all new construction.

- Low-Income Program Eligibility Reform: Existing and emerging low-income solar programs require low-income customers to demonstrate eligibility, which often results in longer times to enroll customers. Emerging solutions have focused on streamlining the eligibility qualification process, for example, by allowing participants in other lowincome assistance programs to automatically qualify for a low-income solar program. ${ }^{22}$ Longer-term solutions could include broader use of income attestations and geographicbased eligibility criteria; however, these longer-term solutions could possibly reduce efforts to enroll customers in multiple low-income programs at the same time, thus providing more need for comprehensive service delivery.

\footnotetext{
21 “Treatment of Solar Virtual Net Energy Metering Credits on Tenant Utility Bills," U.S. Department of Housing and Urban Development. Memorandum. https:/calsomah.org/sites/default/files/docs/SOMAH_HUD Solar_VNEM Credits memo 2019-07-08.pdf.

22 Programs can be energy-related or not (e.g., low-income programs like the Supplemental Nutrition Assistance Program).
} 
- Coordinating Electrification Programs: Rather than being limited by historical usage, LMI households could be allowed to size their PV systems to accommodate contemporaneous or future electrification of their homes, appliances, and if applicable, vehicles. Program harmonization and co-marketing would help enable more one-time installations of solar along with other technologies. Multifamily affordable housing providers likewise could be encouraged through various means, including technical assistance and incentives, to combine solar installation with electrification and electric vehicle charging infrastructure for residents.

\subsubsection{Resilience and Recovery}

\section{Increased Technology Deployment to Support Low-Income Customer Resilience}

Pairing solar with other technologies, for example, storage, can help support low-income customer resilience. Communities considering deploying resilience projects could plan for infrastructure to support critical needs, not only facilities such as hospitals but also facilities that serve low-income populations in cases of grid outages. The positive health and safety impact would be especially significant in areas that do not presently have reliable access to electricity (e.g., some tribal communities).

\section{Use of Pre- and Post-Disaster Mitigation and Recovery Funding for Low-Income Households}

As noted above, research has shown that low-income households and communities suffer disproportionately from disasters, yet many disaster mitigation and recovery programs fail to help the most vulnerable people get back on their feet. Many LMI households do not qualify for disaster loans, and they are especially affected by funding delays or shortfalls. Ensuring LMI households receive effective assistance that includes solar can help LMI communities suffer less damage and recover more quickly and fully.

\subsubsection{Emerging Structures}

Over the next 30 years, there will certainly be program and project designs that we cannot predict today. Emerging areas of design could include creation of local virtual power plants targeted at low-income communities. Similarly, community-based microgrids could both reduce energy burden and create greater resiliency capabilities for low-income communities. Though these structures have not yet been implemented at scale, they and other applications could be targeted to low-income communities.

\subsection{Challenges to LMI Solar Adoption}

Changes over the study period of the Solar Futures Study (2020-2050) could adversely impact equity in the solar PV market. First, as solar markets evolve, some utilities are proposing changes to their rate designs. Some utilities are proposing higher fixed charges in their rate structures. Higher fixed charges, depending on their structure, can result in higher bills for solar adopters (regardless of income); higher charges disproportionately impact LMI households as a fraction of income and in terms of impact on monthly household budgets (Bird et al. 2015). Some utilities and states are also considering changes to net metering, which we did not model for this report but which likewise could have negative impacts on LMI solar adopters, depending on design. See O'Shaughnessy and Shah (2021) for considerations regarding rate design changes. 
Second, as states develop new clean and renewable energy policies, there has been some discussion about whether and how to include access for all customer types. Some argue that if a utility is supplying a large percentage of utility-scale renewable energy to all its customers, there is less need to provide targeted programs, funding, or incentives to a subset of customers, including low-income customers, for distributed solar. Though customers may be getting higher percentages of renewable energy, they would not see the same bill reduction if they were hosting an on-site system; nor would they see any of the other potential benefits specific to distributed solar, such as resilience and community ownership.

Third, changes in financial markets could impact lending and qualification criteria. If lending markets start to become more conservative, lending environments could become more conservative. Feldman, Bolinger, and Schwabe (2020) describe various factors that could influence financing costs for renewable energy projects: changes in interest rates, changes in tax credits, along with other issues, including movement away from power purchase agreements.

Fourth, changes in underlying housing characteristics could make deploying on-site solar more difficult. For single-family homes, this could be roofing or electrical issues that make solar more difficult or costly to install. For multifamily homes, this includes risks that the availability of affordable multifamily housing declines. As the LMI solar market matures, the risk remains that the remaining properties will be those for which installations are more expensive because of roofing, electrical, or other issues.

Fifth, underlying future energy dynamics may present additional barriers to low-income customers. In the Solar Futures Study's High Electrification scenario, low-income customers might be the last to switch from natural gas to electricity, and from internal combustion engines to zero-emission vehicles, without deliberate promotion of equity in electrification-related policies. In such a case, these customers could be adversely affected because (1) they would not install larger solar systems (to account for larger electrified loads) and (2) if rates were not properly designed, they could represent a large share of a gas utility's rate base and thus pay more for the costs of transitioning from natural gas to electricity. 


\section{Conclusions}

Much is known about the barriers that LMI households face when installing solar. This report summarizes key barriers and emerging solutions, and for the first time, projects deployment of on-site, distributed PV by income group and housing type under various scenarios.

If current trends continue, LMI on-site solar would reach around $40 \mathrm{GW}$ of capacity, or about half of what is installed on non-LMI households $(80 \mathrm{GW})$ (Figure 8). This would result in about $18 \%$ of LMI households having on-site PV, compared to $25 \%$ of non-LMI households.

Alternative scenarios include a partial or full incentive for LMI households. We model an incentive as a reduction in the solar price; these reductions in prices could also represent value that is provided through multiple sources, such as tax incentives, solar renewable energy certificates, or philanthropic funding. In the full incentive scenario, LMI on-site solar capacity reaches parity with non-LMI on-site solar capacity in 2025. The parity in deployment levels (GW) translates to LMI households having a greater percentage of solar installed $(33 \%)$ than non-LMI households (23\%) (Figure 8).

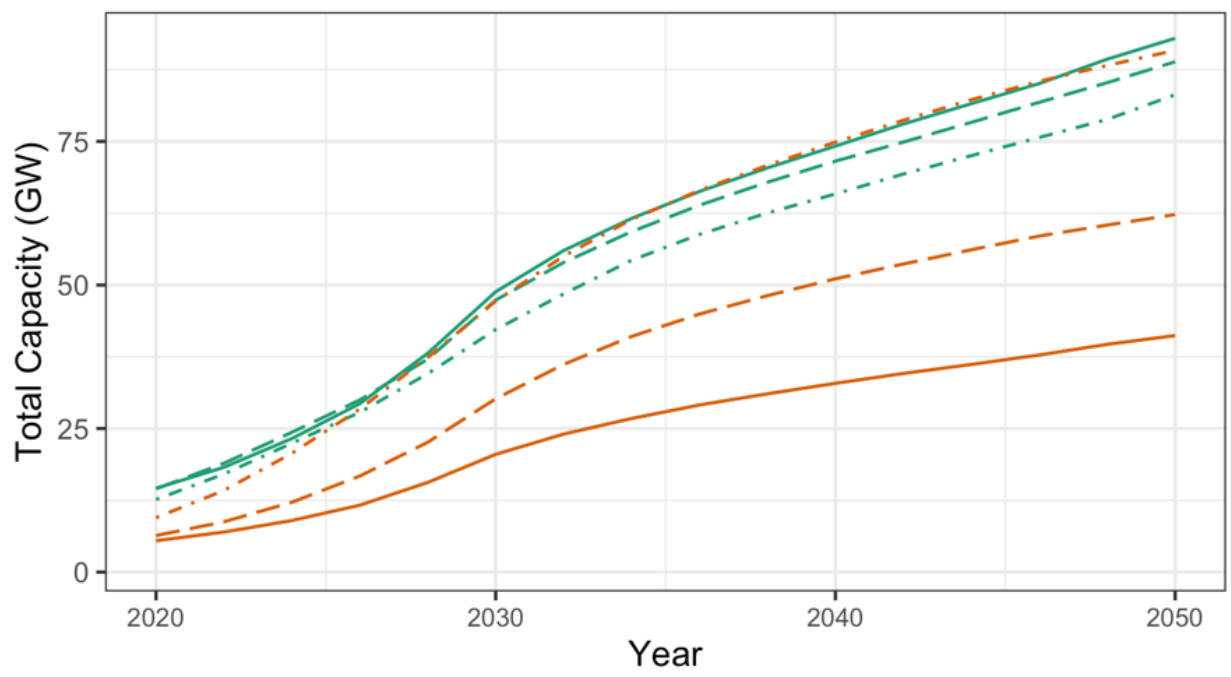

Incentive

- No Incentive

- - Partial Incentive

- . Full Incentive

Income

- High

- Low and Moderate

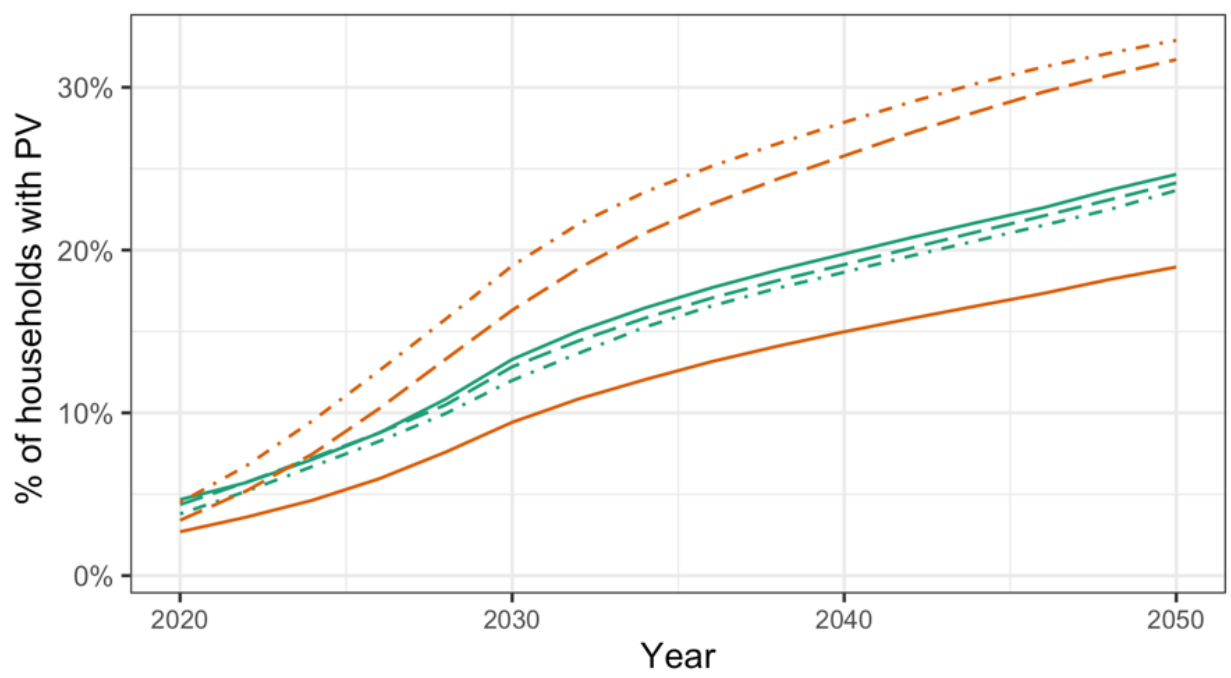

Incentive

- No Incentive

- - Partial Incentive

- . Full Incentive

Income

- High

— Low and Moderate

Figure 8. Solar Deployment by Income and Incentive (2020-2050) 


\section{Key Findings}

The suitable roof area for each market segment can drive solar adoption opportunities for lowincome households, especially with single-family owner-occupied and multifamily renteroccupied buildings. Single-family owner-occupied suitable roof area $\left(27,039 \mathrm{ft}^{2}\right)$ is more than double that of multifamily renter-occupied suitable roof space $\left(10,946 \mathrm{ft}^{2}\right)$, and 5-6 times that of the suitable roof area for single-family renter-occupied $\left(5,252 \mathrm{ft}^{2}\right)$ and multifamily owneroccupied buildings $\left(4,284 \mathrm{ft}^{2}\right)$. Even assuming the split incentive problem had been solved, lowincome single-family owners adopted more with the full incentive (approximately $55 \mathrm{GW}$ by 2050) than single-family renters (approximately $12 \mathrm{GW}$ by 2050). For multifamily buildings, however, under a solved split incentive scenario, solar adoption was nearly ten times greater for low-income multifamily renters than for low-income multifamily owners (12 GW compared to $1.2 \mathrm{GW})$.

The impact of incentives was most pronounced for single-family owner-occupied buildings for low-income households. The full incentive doubled to tripled PV adoption for single-family owner-occupied buildings, depending on whether the Advanced PV prices or Moderate PV prices were used. The full incentive had the most impact on single-family owners by increasing the range of first-year bill savings from $\$ 510-\$ 720$ (no incentive) to $\$ 650-\$ 810$ (full incentive).

Both the partial and full incentives resulted in similar levels of solar adoption by single-family and multifamily renter-occupied buildings across split incentive scenarios. Even though the multifamily renter-occupied suitable roof area was twice that of single-family renter-occupied roof space, the adoption of solar per roof area was double in single-family renter-occupied buildings as compared to multifamily renter-occupied buildings. We also saw similar levels of solar adoption by either addressing the split incentives issue or offering a full incentive, which indicates there might be multiple policy interventions that could address solar adoption challenges in renter-occupied buildings.

Between 2020 and 2050, reducing or eliminating the cost of a solar system for LMI households would provide 48\%-49\% of today's LMI households with access to solar. If a total of \$43 billion-\$127 billion were spent between 2020 and 2050 in either a partial or full incentives, LMI households would receive $\$ 69$ billion-\$101 billion in first year utility bill savings. On an annual basis, this level of funding, \$2.3 billion-\$3.4 billion per year, is similar to the level of funding that is collectively spent by the U.S. Department of Energy's Weatherization Assistance Program, the U.S. Department of Health and Human Services on the Low-income Energy Assistance and Heating Program, and the U.S. Department of Housing and Urban Development on energy assistance and crisis programs annually (Mueller and Ronen 2015).

LMI solar adoption faces several barriers, including finance and funding, community engagement, site suitability, policy and regulatory, and resilience and recovery barriers. In a low-cost solar future, barriers to LMI solar will remain. Solutions are centered on four key questions:

- How can solar be used as a tool to resolve larger societal failures?

- How can solar be delivered to low-income households in a way that saves them money on their electricity bills but also provides other needed services, including energy and non-energy services? 
- How can financial motivations of solar implementers be aligned?

- How can off-site solar solutions and building improvement mandates be used to resolve site suitability issues?

This study has taken a first look at future PV adoption by income group. Remaining questions specific to this analysis include:

- How does deployment vary by state, under the scenarios modeled here? What are the key drivers of any differences among states?

- What is the impact of reducing financing barriers on LMI PV adoption? How does potential reduction in financing barriers compare to providing an incentive?

Additional data needs, and analysis we were unable to conducted for this study, include:

- Data on multifamily renter-occupied solar adoption

- Survey research to establish the solar adoption curve for renter-occupied buildings

- Analysis to answer these questions:

- What are the historical solar access rates by race, ethnicity, environment justice indicators, disaster prone regions, and other indicators for underserved communities? What could future solar adoption look like for these subgroups?

- What are the resilience, grid, health, and real estate benefits of solar adoption for LMI households, especially with respect to communities disadvantaged by air quality, other environmental issues, or natural disasters?

- What is the potential for LMI customers to access solar (and electricity bill reduction) via off-site solar options, such as utility-scale programs, community solar, or other designs?

- What are the implications of distribution system upgrades on LMI communities? For example, at high penetrations of distributed solar, are the required distribution system upgrades concentrated in LMI communities?

- What are the equity implications of the intersections of solar deployment with energy storage and electrification? 


\section{References}

Baker, Shalanda. 2021. Revolutionary Power: An Activist's Guide to the Energy Transition. Island Press.

Barbose, Galen L., Sydney Forrester, Naïm R. Darghouth, and Ben Hoen. 2020. Income Trends among US Residential Rooftop Solar Adopters. Berkeley, CA: Lawrence Berkeley National Laboratory.

Barbose, Galen, Naïm. R. Darghouth, Ben Hoen, and Ryan Wiser. 2018. Income Trends of Residential PV Adopters: An Analysis of Household-Level Income Estimates. Lawrence Berkeley National Laboratory.

Bass, Frank M. 1969. A New Product Growth for Model Consumer Durables. Management Science 15(5): 215-227. https://doi.org/10.1287/mnsc.15.5.215.

Bird, Lori, Carolyn Davidson, Joyce McLaren, and John Miller. 2015. Impact of Rate Design Alternatives on Residential Solar Customer Bills: Increased Fixed Charges, Minimum Bills and Demand-Based Rates. Golden, CO: National Renewable Energy Laboratory. NREL/TP-6A2064850. https://doi.org/10.2172/1225307.

Bird, Stephen, and Diana Hernández. 2012. "Policy Options for the Split Incentive: Increasing Energy Efficiency for Low-Income Renters.” Energy Policy 48: 506-514. https://dx.doi.org/10.1016\%2Fj.enpol.2012.05.053.

Blumstein, Carl, Betsy Krieg, Lee Schipper, and Carl York. 1980. "Overcoming Social and Institutional Barriers to Energy Conservation." Energy 5(4): 355-371.

https://doi.org/10.1016/0360-5442(80)90036-5.

Bolinger, Mark. 2014. An Analysis of the Costs, Benefits, and Implications of Different Approaches to Capturing the Value of Renewable Energy Tax Incentives. Lawrence Berkeley National Laboratory. LBNL-6610E. https://eta-publications.lbl.gov/sites/default/files/lbnl$\underline{6610 \mathrm{e} . p d f}$.

Bolinger, Mark, Joachim Seel, Dana Robson. 2020. Utility-Scale Solar: Empirical Trends in Project Technology, Cost, Performance, and PPA Pricing in the United States, 2019 Edition. Lawrence Berkeley National Laboratory.

https://emp.lbl.gov/sites/default/files/lbnl utility scale solar 2019 edition final.pdf.

Borenstein, Severin, and Lucas W. Davis. 2016. "The Distributional Effects of U. S. Clean Energy Tax Credits." Tax Policy and the Economy 30(1): 191-234.

https://doi.org/10.1086/685597.

Brevoort, Kenneth P., Philipp Grimm, and Michelle Kambara. 2015. "Data Point: Credit Invisibles." Bureau of Consumer Financial Protection Data Point Series 15-1. 
California Department of Community Services and Development. 2018. Low-Income Weatherization Program Fact Sheet. https://www.csd.ca.gov/Shared\%20Documents/LIWP-FactSheet.pdf.

Cook, Jeffrey J., and Lori A. Bird. 2018. Unlocking Solar for Low-and Moderate-Income Residents: A Matrix of Financing Options by Resident, Provider, and Housing Type. Golden, CO: National Renewable Energy Laboratory. NREL/TP-6A20-70477. https://doi.org/10.2172/1416133.

Cook, Jeffrey J., and Monisha Shah. 2018. Reducing Energy Burden with Solar: Colorado's Strategy and Roadmap for States. Golden, CO: National Renewable Energy Laboratory NREL/TP-6A20-70965. https://doi.org/10.2172/1431421.

DOE (U.S. Department of Energy). 2021. Solar Futures Study. Washington, D.C.: U.S. Department of Energy Office of Energy Efficiency and Renewable Energy.

DOE SETO (U.S. Department of Energy Solar Energy Technologies Office). 2020. 2020 Portfolio. DOE/EE-2092.

https://www.energy.gov/sites/prod/files/2020/07/f76/SETO\%20Portfolio\%20Book\%202020.pdf.

Drehobl, Ariel, Lauren Ross, and Roxana Ayala. 2020. How High Are Household Energy Burdens: An Assessment of National and Metropolitan Energy Burdens across the United States. Washington, D.C.: American Council for an Energy-Efficient Economy. https://www.aceee.org/research-report/u2006.

EIA (U.S. Energy Information Administration). 2018. "2015 Residential Energy Consumption Survey (RECS) Data.” May 2018. https://www.eia.gov/consumption/residential/data/2015/index.php?view=consumption\#summary.

Feldman, David, Mark Bolinger, and Paul Schwabe. 2020. Current and Future Costs of Renewable Energy Project Finance Across Technologies. Golden, CO: National Renewable Energy Laboratory. NREL/TP-6A20-76881. https://doi.org/10.2172/1660124.

Fernald, Marcia. 2013. America's Rental Housing: Evolving Markets and Needs. Cambridge, MA: Joint Center for Housing Studies of Harvard University.

Gagnon, Pieter, Robert Margolis, Jennifer Melius, Caleb Phillips, and Ryan Elmore. 2016. Rooftop Solar Photovoltaic Technical Potential in the United States: A Detailed Assessment. Golden, CO: National Renewable Energy Laboratory. NREL/TP-6A20-65298. https://doi.org/10.2172/1236153.

Gallucci, Maria. 2019. "Energy Equity: Bringing Solar Power to Low-Income Communities." Yale Environment 360 (April 4, 2019). https://e360.yale.edu/features/energy-equity-bringingsolar-power-to-low-income-communities.

Grid Alternatives and Vote Solar. 2018. "Low-Income Solar Policy Guide: District of Columbia." https://www.lowincomesolar.org/best-practices/district-of-columbia/. 
Hallegatte, Stephane, Adrien Vogt-Schilb, Mook Bangalore, and Julie Rozenberg. 2016. "Unbreakable: Building the Resilience of the Poor in the Face of Natural Disasters." Climate Change and Development Series. World Bank Publications. https://doi.org/10.1596/978-1-46481003-9.

Hawaii Public Utilities Commission. 2020. Summary of Phase 2 Decision and Order Establishing a PBR Framework. Public Utilities Commission State of Hawaii. https://puc.hawaii.gov/wp-content/uploads/2020/12/PBR-Phase-2-DO-5-PageSummary.Final .12-22-2020.pdf.

Heeter, Jenny S., Lori A. Bird, Eric J. O’Shaughnessy, and Samuel Koebrich. 2018. Design and Implementation of Community Solar Programs for Low-and Moderate-Income Customers. Golden, CO: National Renewable Energy Laboratory. NREL/TP-6A20-71652. https://doi.org/10.2172/1488510.

Heeter, Jenny S., Eric O’Shaughnessy, and Gabriel Chan. 2020. Sharing the Sun: Understanding Community Solar Deployment and Subscriptions. Golden, CO: National Renewable Energy Laboratory. NREL/PR-6A20- 76853. https://doi.org/10.2172/1669463.

Holtje, Melissa. "Segregation, Profiling, and Opportunism: 20 Resources About Housing and Racism.” August 2020. https://www.homelight.com/blog/buyer-books-on-racism-in-real-estate/

Hynek, Don, Megan Levy, and Barbara Smith. 2012. "Follow the Money: Overcoming the Split Incentive for Effective Energy Efficiency Program Design in Multi-Family Buildings." ACEEE Summer Study on Energy Efficiency in Buildings 6-148. https://www.aceee.org/files/proceedings/2012/data/papers/0193-000192.pdf.

Imperial Irrigation District. 2019. "IID \& Citizens Commission Community Solar Project Dedicated to Low-Income Customers." News release. https:/www.iid.com/about-iid/newsresources/news-releases/-item-709.

Joint Center for Housing Studies. 2020. America's Rental Housing: 2020. Harvard University.

Kann, Shayle, and Attila Toth. 2017. How Wealthy are Residential Solar Customers? Household Income and Solar Adoption in the US. GTM Research.

Kienbaum, Katie, and John Farrell. 2021. The National Impact of 30 Million Solar Homes: A Vision for an Equitable Economic Recovery Built on Climate Protection and Energy Democracy. Institute for Local Self-Reliance, Solar United Neighbors Action, Initiative for Energy Justices, and Solar United Neighbors. https://ilsr.org/impact-of-30-million-solar-homes-report/.

Lee, Dalbyul. 2018. "The Impact of Natural Disasters on Neighborhood Poverty Rate: A Neighborhood Change Perspective.” Journal of Planning Education and Research (2018). https://doi.org/10.1177\%2F0739456X18769144.

Levinson, Arik, and Scott Niemann. 2004. "Energy Use by Apartment Tenants When Landlords Pay for Utilities." Resource and Energy Economics 26(1): 51-75. https://doi.org/10.1016/S0928$\underline{7655(03) 00047-2 .}$. 
Lukanov, Boris R., and Elena M. Krieger. 2019. "Distributed Solar and Environmental Justice: Exploring the Demographic and Socio-Economic Trends of Residential PV Adoption in California." Energy Policy 134: 110935. https://doi.org/10.1016/j.enpol.2019.110935.

Memmott, Trevor, Sanya Carley, Michelle Graff, and David M. Konisky. 2021.

"Sociodemographic Disparities in Energy Insecurity Among Low-Income Households Before and During the COVID-19 Pandemic." Nature Energy 6: 1-8. https://doi.org/10.1038/s41560020-00763-9.

Melvin, Jesse. 2018. "The Split Incentives Energy Efficiency Problem: Evidence of Underinvestment by Landlords.” Energy Policy 115: 342-352. https://doi.org/10.1016/j.enpol.2017.11.069.

Mooney, Meghan, and Ben Sigrin. 2018. Rooftop Energy Potential of Low Income Communities in America: REPLICA. National Renewable Energy Laboratory. https://data.nrel.gov/submissions/81.

Morehouse, Catherine. 2020. "Federal Stimulus Includes Wind, Solar Tax Credit Extensions, Adds First Us Offshore Wind Tax Credit." Utility Dive (December 22, 2020). https://www.utilitydive.com/news/federal-stimulus-includes-wind-solar-tax-credit-extensionsadds-first-us/592572/.

Mueller, James A., and Amit Ronen. 2015. Summary for Policymakers: Bridging the Solar Income Gap. The George Washington University: GW Solar Institute. Working Paper. https://solar.gwu.edu/sites/g/files/zaxdzs2391/f/image/GWSIBridging\%20the \%20Solar\%20Income $\% 20$ Gap $\% 20$ Working $\% 20$ Paper_0.pdf.

Nie, Hongguang, René Kemp, Jin-Hua Xu, Véronique Vasseur, and Ying Fan. 2020. "Split Incentive Effects on the Adoption of Technical and Behavioral Energy-Saving Measures in the Household Sector in Western Europe." Energy Policy 140: 111424.

https://doi.org/10.1016/j.enpol.2020.111424.

NREL (National Renewable Energy Laboratory). 2021. "2021 Annual Technology Baseline.” Golden, CO: National Renewable Energy Laboratory. https://atb.nrel.gov/.

O'Connor, Megan. 2018. "All in the Community: Using Community Solar Gardens to Bring the Benefits of Renewable Energy to Low-Income Communities." Georgetown Environmental Law Review 31: 391.

O'Shaughnessy, Eric, Galen Barbose, Ryan Wiser, Sydney Forrester, and Naïm Darghouth. 2021. "The Impact of Policies and Business Models on Income Equity in Rooftop Solar Adoption.” Nature Energy 6(1): 84-91. https://doi.org/10.1038/s41560-020-00724-2.

O'Shaughnessy, Eric, and Monisha Shah. 2021. The Demand-Side Opportunity: The Roles of Distributed Solar and Building Energy Systems in a Decarbonized Grid. Golden, CO: National Renewable Energy Laboratory. NREL/TP-6A20-80527. https://www.nrel.gov/docs/fy21osti/80527.pdf. 
Paulos, Bentham. 2017. Bringing the Benefits of Solar Energy to Low-Income Consumers: A Guide for States and Municipalities. Montpelier, VT: Clean Energy States Alliance. https://www.cesa.org/wp-content/uploads/Bringing-the-Benefits-of-Solar-to-Low-IncomeConsumers.pdf.

Pastor, Manuel, Robert D. Bullard, James K. Boyce, Alice Fothergill, Rachel Morello-Frosch, and Beverly Wright. 2006. In the Wake of the Storm: Environment, Disaster, and Race After Katrina. New York: Russell Sage Foundation.

Perrin, A., 2018. Internet/Broadband Fact Sheet. Pew Research Center.

Ramanan, Abbe, Shauna Beland, Yasmin Yacoby, and Nicole Hernandez Hammer. 2021. Community Outreach and Solar Equity: A Guide for States on Collaborating with CommunityBased Organizations. Clean Energy States Alliance.

Reames, Tony G. 2020. "Distributional Disparities in Residential Rooftop Solar Potential and Penetration in Four Cities in the United States." Energy Research and Social Science 69: 101612. https://doi.org/10.1016/j.erss.2020.101612.

Rodriquez, Matthew, and Lauren Zeise. 2017. CalEnviroScreen 3.0: Update to the California Communities Environmental Health Screening Tool. California Environmental Protection Agency (CalEPA), California Office of Environmental Health Hazard Assessment (OEHHA). https://oehha.ca.gov/media/downloads/calenviroscreen/report/ces3report.pdf.

Ross, Tracey. 2013. "A Disaster in the Making: Addressing the Vulnerability of Low-Income Communities to Extreme Weather.” August 19, 2013. Center for American Progress.

Samwick, Andrew A., 1998. "Discount rate heterogeneity and social security reform," Journal of Development Economics, Elsevier, vol. 57(1), pages 117-146, October.

Sanders, Robert G., and Lewis Milford. 2017. A Resilient Power Capital Scan: How Foundations Could Use Grants and Investments to Advance Solar and Storage in Low-Income Communities. Montpelier, VT: Clean Energy Group. A Report to The Kresge Foundation, Surdna Foundation, and The JPB Foundation. https://www.cleanegroup.org/wpcontent/uploads/Capital-Scan-Feb2017.pdf.

Sigrin, Benjamin O., and Meghan E. Mooney. 2018. Rooftop Solar Technical Potential for Lowto-Moderate Income Households in the United States. Golden, CO: National Renewable Energy Laboratory. NREL/TP-6A20-70901.

Snell, John, Megan Sandel, Jean Zotter, Deborah George, and Kate Bennett. 2000. "Public Health Concerns and Opportunities for Energy Efficiency Upgrades in Subsidized Housing." In Proceedings of the 2000 ACEEE Summer Study on Energy Efficiency in Buildings.

Solstice. 2018. Energy Score: An Alternative to FICO Credit Requirements for Low-to-Moderate Income Community Solar. Solstice. https://solstice.us/wp-content/uploads/2018/08/2018-08-09EnergyScore.pdf. 
Stanton, Tom. 2020. "Solar Energy that Pays for Low-Income Customers and Communities." NRRI Insights (December 2020). https://pubs.naruc.org/pub/46965D7D-155D-0A36-315D58319B591EB8.

Sunter, Deborah A., Sergio Castellanos, and Daniel M. Kammen. 2019. "Disparities in Rooftop Photovoltaics Deployment in the United States by Race and Ethnicity." Nature Sustainability 2: 71-76. https://doi.org/10.1038/s41893-018-0204-z.

Teron, Lemir, and Susan S. Ekoh. 2018. "Energy Democracy and the City: Evaluating the Practice and Potential of Municipal Sustainability Planning." Frontiers in Communication 3(8): 1-5. https://doi.org/10.3389/fcomm.2018.00008.

Ulrich, Elaine, Monisha R. Shah, Joseph Pereira, David Hepinstall, David J. Feldman, Jeffrey J. Cook, Amy Hollander, et al. 2018. "Using Federal Energy Assistance Funds for PV to Reduce Energy Burden for Low-Income Households." 2018 ACEEE Summer Study on Energy Efficiency in Buildings: Making Efficiency Easy and Enticing.

Wolske, Kimberly S. 2020. "More Alike than Different: Profiles of High-Income and LowIncome Rooftop Solar Adopters in the United States." Energy Research and Social Science 63: 101399. https://doi.org/10.1016/j.erss.2019.101399. 